\title{
Highly Efficient Fixation of Carbon Dioxide at RT and Atmospheric \\ Pressure Conditions: Influence of Polar Functionality on Selective Capture and Conversion of $\mathrm{CO}_{2}$
}

\author{
Rajesh Das and C. M. Nagaraja*a \\ Department of Chemistry, Indian Institute of Technology Ropar, Rupnagar 140001,
}

Punjab, India.Tel:91-1881-242229. Email: cmnraja@iitrpr.ac.in

http://www.iitrpr.ac.in/CMNagaraja

\section{Contents}

Materials and methods

Experimental section

Synthesis of MOF-SO${ }_{3} \mathrm{H}$

Synthesis of MOF-SO $\mathrm{SAg}_{3}$

Synthesis of Ag(I)@UiO-66

Gas adsorption measurements

Catalytic cycloaddition reactions of $\mathrm{CO}_{2}$ with propargylic alcohols

Analysis of gas adsorption isotherms

Figure S1. PXRD patterns of $\mathrm{MOF}-\mathrm{SO}_{3} \mathrm{H}$, (a) simulated pattern, (b) as-synthesized, (c) for MOF-SO ${ }_{3} \mathrm{Ag}$ and (d) recycled sample of $\mathrm{MOF}-\mathrm{SO}_{3} \mathrm{Ag}$ after five catalytic cycles.

Figure S2. FT-IR spectra of MOF-SO ${ }_{3} \mathrm{H}$ and $\mathrm{MOF}-\mathrm{SO}_{3} \mathrm{Ag}$.

Figure S3. UV-Vis spectra of $\mathrm{MOF}-\mathrm{SO}_{3} \mathrm{H}$ and $\mathrm{MOF}-\mathrm{SO}_{3} \mathrm{Ag}$.

Figure S4. EDS spectra of (a) $\mathrm{MOF}-\mathrm{SO}_{3} \mathrm{H}$ and (b) $\mathrm{MOF}-\mathrm{SO}_{3} \mathrm{Ag}$.

Figure S5. PXRD patterns of UiO-66 (a) simulated pattern, (b) as-synthesized, (c) Ag(I)@UiO-66 and (d) recycled sample of Ag(I)@UiO-66 after reaction. 
Figure S6. View of $\mathrm{Zr}-\mathrm{O}$ cluster/SBU of UiO-66 MOF showing the presence of hydroxide groups.

Figure S7. $\mathrm{N}_{2}$ adsorption-desorption isotherms for UiO-66 and Ag(I)@UiO-66 MOF carried out at $77 \mathrm{~K}$.

\section{Analysis of gas adsorption isotherms}

Figure S8. Carbon dioxide adsorption isotherm of $\mathrm{MOF}-\mathrm{SO}_{3} \mathrm{H}$ carried out at $273 \mathrm{~K}$.

Figure S9. Carbon dioxide adsorption isotherm of $\mathrm{MOF}-\mathrm{SO}_{3} \mathrm{H}$ carried out at $298 \mathrm{~K}$.

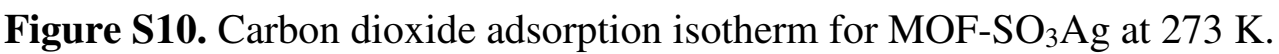

Figure S11. Carbon dioxide adsorption isotherm for MOF-SO $3 \mathrm{Ag}$ at $298 \mathrm{~K}$.

Figure S12. Carbon dioxide adsorption isotherm of $\mathrm{Ag}(\mathrm{I}) @ \mathrm{UiO}-66$ carried out at $273 \mathrm{~K}$.

Figure S13. Carbon dioxide adsorption isotherm of $\mathrm{Ag}(\mathrm{I}) @ \mathrm{UiO}-66$ carried out at $298 \mathrm{~K}$.

Table S1. Comparison of $\mathrm{CO}_{2}$ heat of adsorption $\left(\mathrm{Q}_{\mathrm{st}}\right)$ value for $\mathrm{MOF}-\mathrm{SO}_{3} \mathrm{Ag}$ with UiO-66 based MOFs.

Figure S14. Calculation of Henry selectivity constants for gases $\mathrm{CO}_{2}, \mathrm{Ar}, \mathrm{H}_{2}$ and $\mathrm{N}_{2}$.

Figure S15. PXRD patterns of $\mathrm{MOF}-\mathrm{SO}_{3} \mathrm{Ag}$ (a) simulated pattern, (b) Activated $\mathrm{MOF}-\mathrm{SO}_{3} \mathrm{Ag}$ and (c) After 5 cycles of $\mathrm{CO}_{2}$ adsorption.

Figure S16. Reaction progress for cyclic carboxylation of 2-Methyl-3-butyn-2-ol with $\mathrm{CO}_{2}$ catalysed by MOF-SO 3 Ag.

Figure S17. ${ }^{1} \mathrm{HNMR}\left(\mathrm{CDCl}_{3}, 400 \mathrm{MHz}\right)$ spectra for the cyclic carboxylation of 2-Methyl-3butyn-2-ol catalysed by MOF-SO 3 Ag.

Figure S18. ${ }^{13} \mathrm{C}$ NMR $\left(\mathrm{CDCl}_{3}, 400 \mathrm{MHz}\right)$ spectra for the cyclic carboxylation of 2-Methyl-3butyn-2-ol using MOF-SO ${ }_{3} \mathrm{Ag}$ as catalyst.

Figure S19. ${ }^{1} \mathrm{HNMR}\left(\mathrm{CDCl}_{3}, 400 \mathrm{MHz}\right)$ spectra for the cyclic carboxylation of 2-Methyl-3butyn-2-ol catalysed by Ag(I)@UiO-66. 
Figure S20. ${ }^{1} \mathrm{HNMR}\left(\mathrm{CDCl}_{3}, 400 \mathrm{MHz}\right)$ spectra for three-component reaction between $\mathrm{CO}_{2}$, 2-Methyl-3-butyn-2-ol and n-butylamine using $\mathrm{MOF}-\mathrm{SO}_{3} \mathrm{Ag}$ as catalyst.

Figure S21. ${ }^{13} \mathrm{C} \mathrm{NMR}\left(\mathrm{CDCl}_{3}, 400 \mathrm{MHz}\right)$ spectra for three-component reaction between $\mathrm{CO}_{2}$, 2-Methyl-3-butyn-2-ol and n-butylamine using $\mathrm{MOF}-\mathrm{SO}_{3} \mathrm{Ag}$ as catalyst.

Figure S22. ${ }^{1} \mathrm{HNMR}\left(\mathrm{CDCl}_{3}, 400 \mathrm{MHz}\right)$ spectra for the cycloaddition reaction of 2-Methyl-3butyn-2-ol using MOF-SO $\mathrm{S}_{3} \mathrm{Ag}$ as catalyst for fifth cycle.

Scheme S1. Plausible mechanism for catalytic carboxylative cyclization of propargylic alcohol with $\mathrm{CO}_{2}$ catalysed by $\mathrm{MOF}-\mathrm{SO}_{3} \mathrm{Ag}$.

\section{Materials and methods}

All reagents used in this study were commercially available and used as received without further purification. Zirconyl chloride and monosodiun 2-sulfoterephthalic acid were purchased from Sigma Aldrich Chemical Co. Thermogravimetric analysis (TGA) of MOF$\mathrm{SO}_{3} \mathrm{H}$ and MOF-SO ${ }_{3} \mathrm{Ag}$ was carried out on Mettler Toledo Thermogravimetric analyzer in the $\mathrm{N}_{2}$ atmosphere. The phase-purity of the MOF samples was confirmed by powder XRD recorded on a PANalytical's X'PERT PRO diffractometer using $\mathrm{CuK}_{\alpha}$ radiation $(\mathrm{k}=1.542 \AA$; $40 \mathrm{kV}, 20 \mathrm{MA}$ ). Fourier transform infrared (FT-IR) spectra of the samples were recorded on a Perkin Elmer FTIR spectrometer.

\section{Experimental section}

\section{Synthesis of MOF-SO $3 \mathrm{H}$}

The MOF-SO ${ }_{3} \mathrm{H}$ was synthesized by following the previously reported procedure with further modification. ${ }^{1}$ Monosodium 2-sulfoterephthalic acid $(0.5 \mathrm{mmol})$ was dissolved in $6 \mathrm{~mL}$ of water to which $0.5 \mathrm{mmol}$ of Zirconyl chloride octahydrate and $4 \mathrm{~mL}$ of acetic acid were added. The resulting mixture was stirred at room temperature for 15 minutes and then refluxed for 24h. After which time the reaction mixture was centrifuged, washed with water thoroughly and dried under vacuum. The phase-purity of the as-synthesised sample was confirmed by powder 
XRD analysis. FT-IR (KBr, cm-1): 1586 (m), 1488 (w), 3211 (w), 1409 (s), 1277 (m), 1165 (s), $1074(\mathrm{~s}), 1018(\mathrm{~m}), 767(\mathrm{w})$ and $650(\mathrm{~s})$.

\section{Synthesis of MOF-SO3Ag}

The activated sample of MOF-SO ${ }_{3} \mathrm{H}(0.02 \mathrm{mmol})$ was soaked in $10 \mathrm{~mL}$ aqueous solution of $\mathrm{AgNO}_{3}(0.3 \mathrm{mmol})$ taken in a $30 \mathrm{~mL}$ culture tube placed in an ice bath. The tube was placed on a shaker with a shaking rate of $100 \mathrm{rpm}$ for $3 \mathrm{~h}$. The solid was filtered out and washed by water thoroughly and dried under vacuum. The activated sample of $\mathrm{MOF}-\mathrm{SO}_{3} \mathrm{Ag}$ exhibits a mass growth of $4 \%$ compared with the parent sample $\mathrm{MOF}-\mathrm{SO}_{3} \mathrm{H}$, which was also confirmed by microwave-plasma atomic emission spectroscopy (MP-AES) analysis. FT-IR $\left(\mathrm{KBr}, \mathrm{cm}^{-1}\right)$ : $1586(\mathrm{~m}), 1488(\mathrm{w}), 3211(\mathrm{w}), 1409$ (s), 1277 (m), $1180(\mathrm{~s}), 1074(\mathrm{~s}), 1018(\mathrm{~m}), 767$ (w) and $650(\mathrm{~s})$.

\section{Synthesis of Ag(I)@UiO-66}

The UiO-66 was synthesized by following the previously reported procedure with further modification ${ }^{2}$. In a typical synthesis, a mixture of $\mathrm{ZrOCl}_{2} .8 \mathrm{H}_{2} \mathrm{O}(3.22 \mathrm{~g}, 10 \mathrm{mmol}), 1$, 4benzenedicarboxylic acid $\left(\mathrm{H}_{2} \mathrm{BDC}\right)(1.6 \mathrm{~g}, 10 \mathrm{mmol})$, and $50 \mathrm{ml}$ of DMF was taken in round bottom flask, which was fitted with reflux condenser. Reaction mixture was stirred for 15 min at ambient condition and $1.6 \mathrm{ml}$ of concentrated $\mathrm{HCl}(19.2 \mathrm{mmol})$ was added to the reaction mixture at ambient condition. Temperature of the reaction mixture was elevated to $150{ }^{\circ} \mathrm{C}$ using oil-bath and the reaction was continued for $24 \mathrm{~h}$ under open air atmosphere. The resultant white solid was filtered and washed with DMF and dried. Dried product was again taken in 50 $\mathrm{mL}$ of DMF and stirred overnight at ambient condition to remove unreacted $\mathrm{H}_{2} \mathrm{BDC}$. Product was filtered and dried at $100{ }^{\circ} \mathrm{C}$ for $2 \mathrm{~h}$. Finally, the obtained product was taken in $25 \mathrm{~mL}$ of methanol and stirred overnight at ambient condition. Product was filtered and again taken in fresh methanol. This methanol treatment process was performed thrice to remove most of the DMF from the product. Finally the product was dried in oven at $100{ }^{\circ} \mathrm{C}$ for $12 \mathrm{~h}$. The activated 
sample of UiO-66 (0.02 mmol) was soaked in $10 \mathrm{~mL}$ aqueous solution of $\mathrm{AgNO}_{3}(0.3 \mathrm{mmol})$ taken in a $30 \mathrm{~mL}$ culture tube placed in an ice bath. The tube was placed on a shaker with a shaking rate of $100 \mathrm{rpm}$ for $3 \mathrm{~h}$. The solid was filtered out and washed by water thoroughly and dried under vacuum. The phase-purity of the as-synthesised sample was confirmed by powder XRD analysis.

\section{Gas adsorption measurements}

Gas adsorption measurements of the samples were performed on a Quantachrome's QUADRASORB-SI automatic volumetric instrument using ultrapure (99.995\%) $\mathrm{H}_{2}, \mathrm{Ar}, \mathrm{N}_{2}$ and $\mathrm{CO}_{2}$ gases. Prior to adsorption measurements, the samples $(\sim 0.10 \mathrm{~g})$ were activated by heating at RT under vacuum (18 mTorr) for $15 \mathrm{~h}$. The $\mathrm{N}_{2}$ adsorption measurements are carried out at $77 \mathrm{~K}$ and $\mathrm{CO}_{2}$ adsorption measurements are done at 273 and $298 \mathrm{~K}$. The temperatures, 273 and $298 \mathrm{~K}$ were achieved by using water chiller with appropriate coolants. Whereas, $77 \mathrm{~K}$ was achieved by using liquid nitrogen and the dead volume of the sample cell was determined using He gas (99.995\%).

\section{Catalytic cycloaddition reactions of $\mathrm{CO}_{2}$ with propargylic alcohols}

Catalytic cyclic carboxylation reactions of alkyne molecules (propargylic alcohols and primary amines) with $\mathrm{CO}_{2}$ were carried out in a glass reactor $(50 \mathrm{~mL})$ under $\mathrm{RT}$ and 1 bar $\mathrm{CO}_{2}$. Prior to catalytic reactions, the catalyst was activated at $323 \mathrm{~K}$ for $15 \mathrm{~h}$ under vacuum to remove guest solvent molecules. The substrates were taken in the reactor at RT and the reactor was flushed with $\mathrm{CO}_{2}$ thrice and then 1 bar $\mathrm{CO}_{2}$ pressure was maintained and the contents were stirred at RT. After $24 \mathrm{~h}$, the MOF-SO 3 Ag catalyst was separated from the reaction mixture by filtration and the catalytic conversions were determined by ${ }^{1} \mathrm{H}$ NMR spectra of the filtrate using $\mathrm{CDCl}_{3}$ solvent. The recovered catalyst was washed with methanol three times and activated at $323 \mathrm{~K}$ under vacuum for $15 \mathrm{~h}$ and reused for the subsequent catalytic cycles. 


\section{Analysis of gas adsorption isotherms}

Clausius-Clapeyron Equation ${ }^{3}$ was used to calculate the enthalpies of carbon dioxide adsorption. By using Langmuir Freundlich equation ${ }^{4}$ an accurate fit was retrieved which gives a precise prediction of carbon dioxide adsorbed at saturation. A modification of ClausiusClapeyron equation is used for calculations.

$$
\ln \left[\frac{P_{1}}{P_{2}}\right]=\Delta H_{\text {ads }} \times\left[\frac{T_{2}-T_{1}}{R \times T_{2} T_{1}}\right] \ldots \ldots . .(1)
$$

where, $P_{1}$ and $P_{2}=$ pressures for isotherm at $273 \mathrm{~K}$ and $298 \mathrm{~K}$ respectively.

$\mathrm{T}_{1}$ and $\mathrm{T}_{2}=$ temperatures for isotherm at $273 \mathrm{~K}$ and $298 \mathrm{~K}$ respectively.

$$
\begin{aligned}
& \Delta \mathrm{H}_{\mathrm{ads}}=\text { Enthalpy of adsorption. } \\
& \mathrm{R}=\text { Universal gas constant }(8.314 \mathrm{~J} / \mathrm{K} / \mathrm{mol})
\end{aligned}
$$

Pressure is a function of amount of gas adsorbed which was determined by using the LangmuirFreundlich fit.

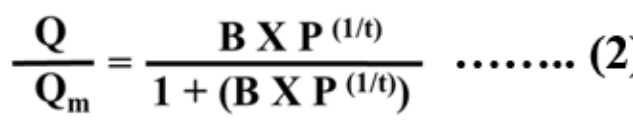

where, $Q=$ moles of gas adsorbed.

$$
\mathrm{Q}_{\mathrm{m}}=\text { moles of gas adsorbed at saturation. }
$$

$\mathrm{B}$ and $\mathrm{t}=$ constants.

$\mathrm{P}=$ Pressure

By rearranging equation (2) we get equation (3) 


$$
P=\left[\frac{Q / Q_{m}}{B-\left(B \times Q / Q_{m}\right)}\right]^{t} \ldots \ldots \ldots(3)
$$

Substituting equation (3) into equation (1) we get

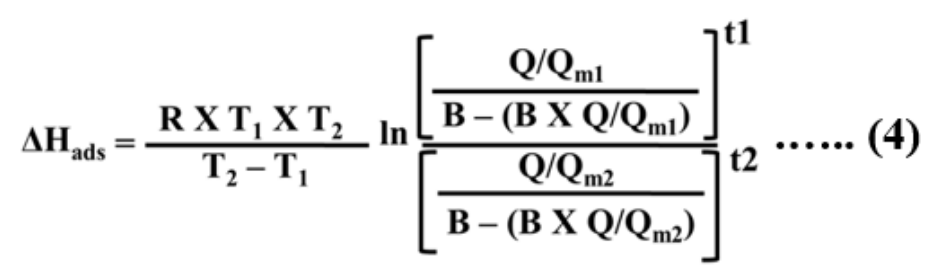

In equation (4), subscript 1 and 2 are representing data corresponding to 273 and 298K in case of carbon dioxide gas.

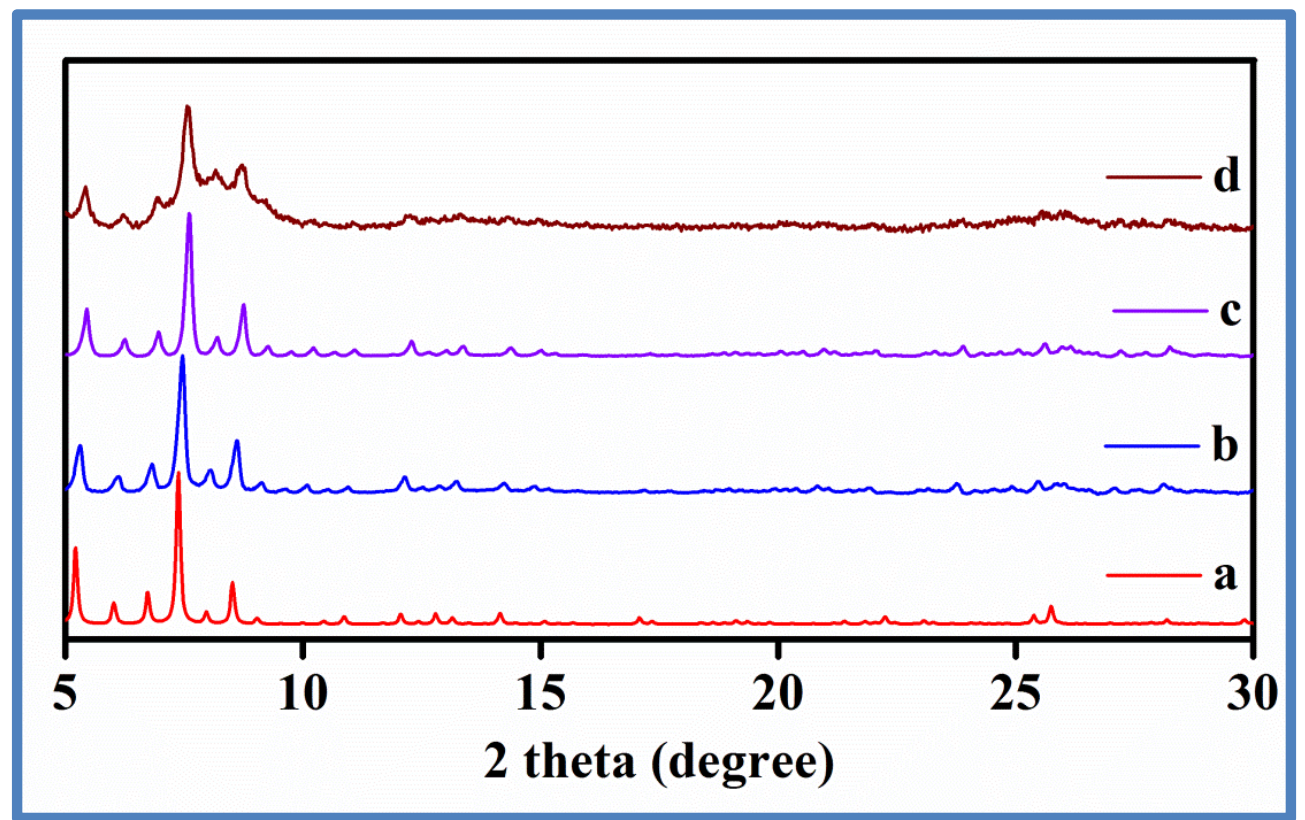

Figure S1. PXRD patterns of $\mathrm{MOF}-\mathrm{SO}_{3} \mathrm{H}$ (a) simulated pattern, (b) as-synthesized, (c) for MOF-SO $\mathrm{S}_{3} \mathrm{Ag}$ and (d) recycled sample of $\mathrm{MOF}-\mathrm{SO}_{3} \mathrm{Ag}$ after five catalytic cycles. 


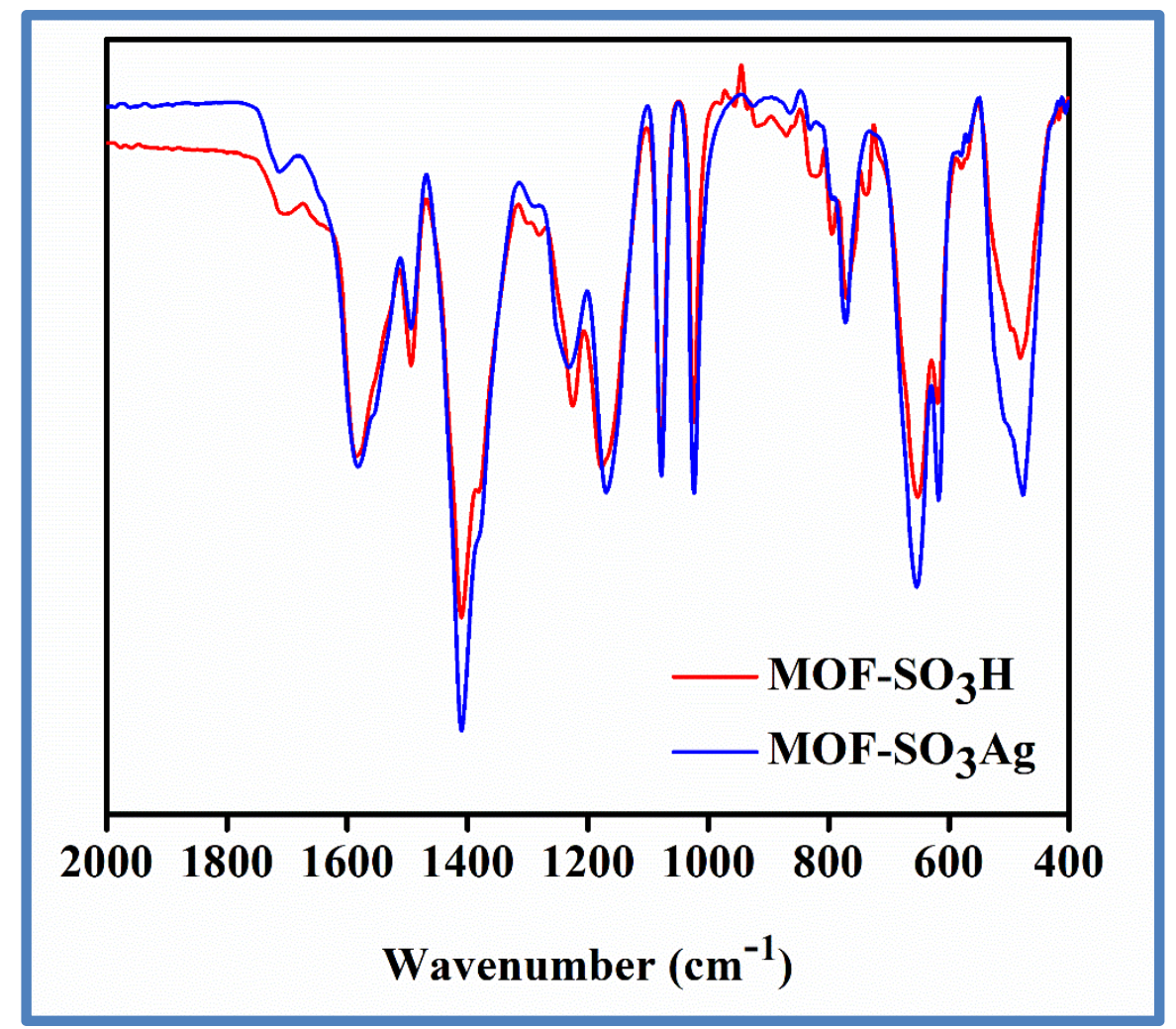

Figure S2. FT-IR spectra of $\mathrm{MOF}-\mathrm{SO}_{3} \mathrm{H}$ and $\mathrm{MOF}-\mathrm{SO}_{3} \mathrm{Ag}$.

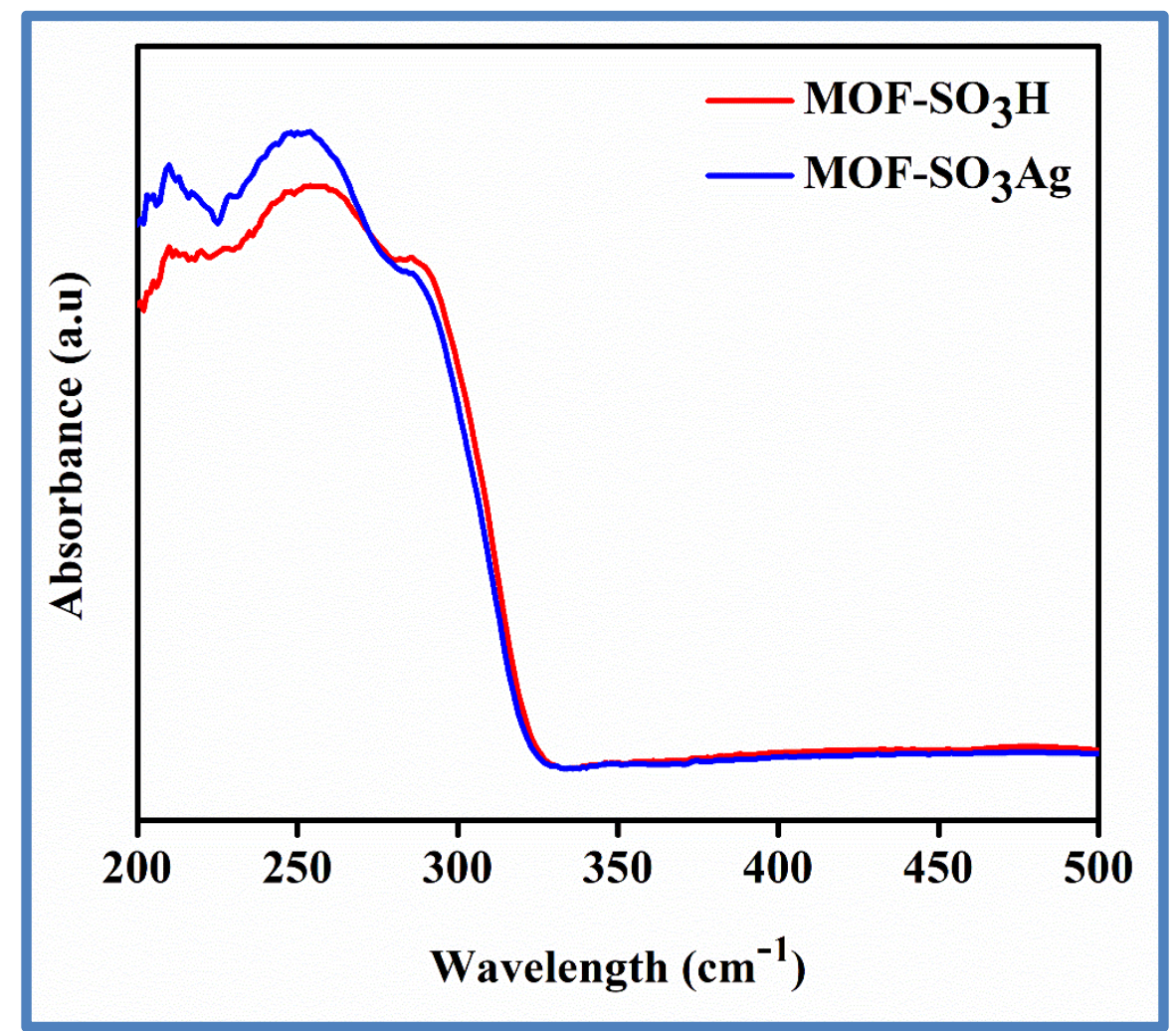

Figure S3. UV-Vis spectra of $\mathrm{MOF}-\mathrm{SO}_{3} \mathrm{H}$ and $\mathrm{MOF}-\mathrm{SO}_{3} \mathrm{Ag}$. 


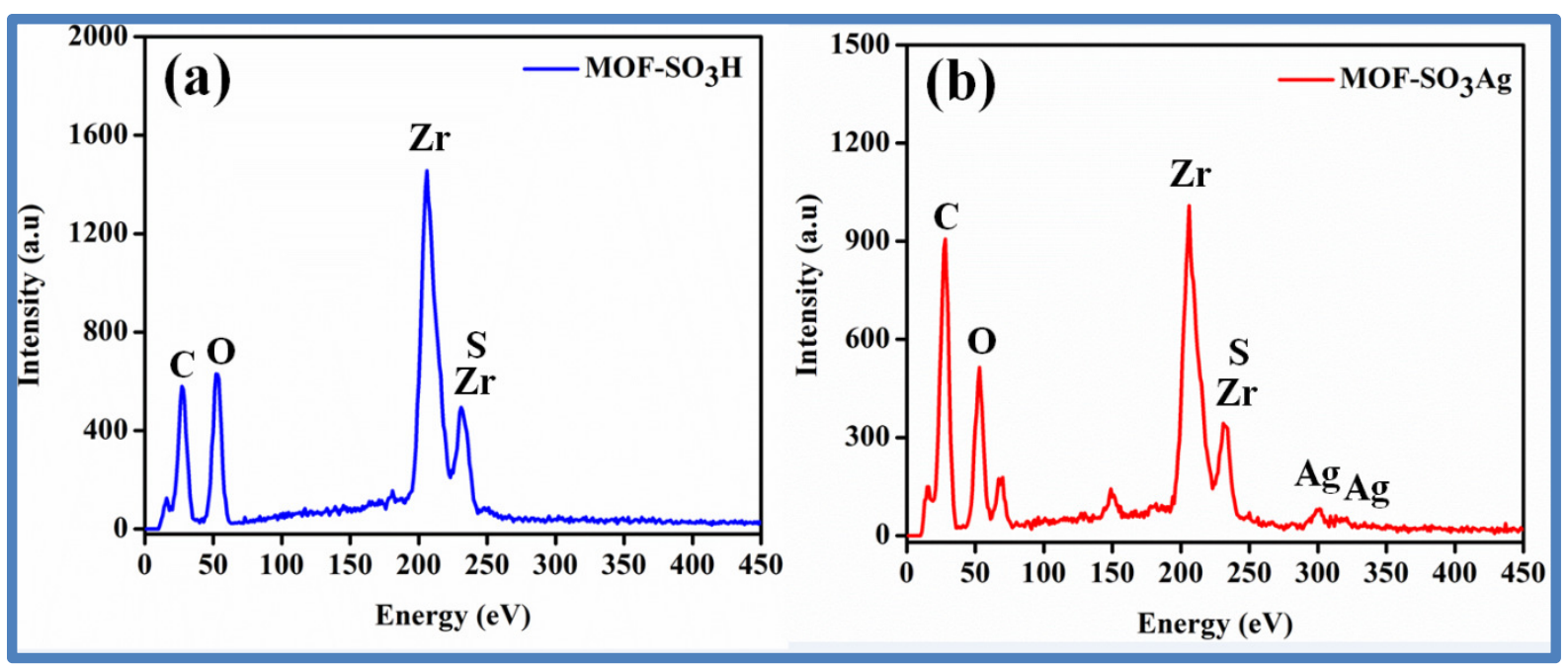

Figure S4. EDS spectra of (a) $\mathrm{MOF}-\mathrm{SO}_{3} \mathrm{H}$ and (b) $\mathrm{MOF}-\mathrm{SO}_{3} \mathrm{Ag}$.

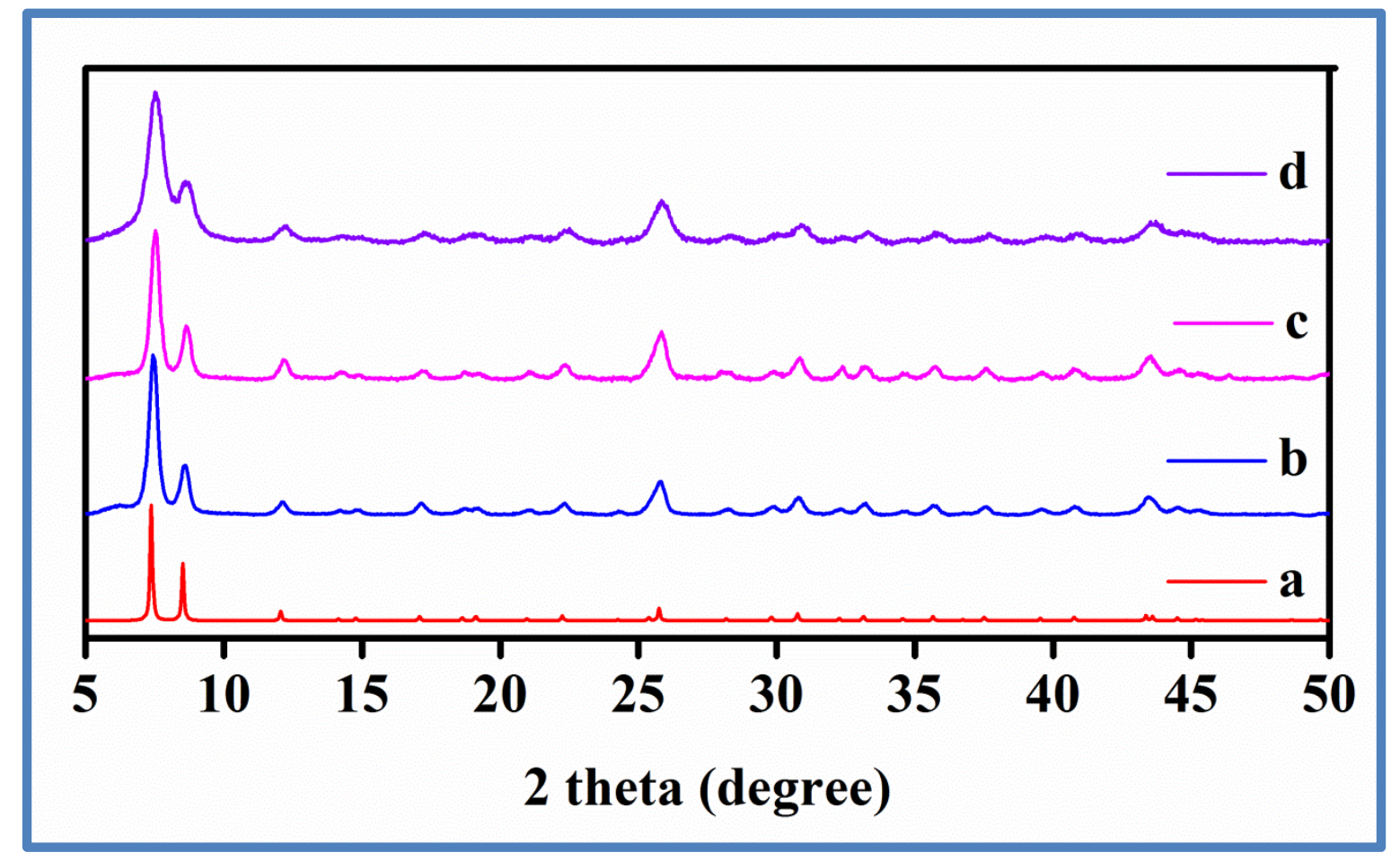

Figure S5. PXRD patterns of UiO-66 (a) simulated pattern, (b) as-synthesized, (c) Ag(I)@UiO-66 and (d) recycled sample of Ag(I)@UiO-66 after reaction. 


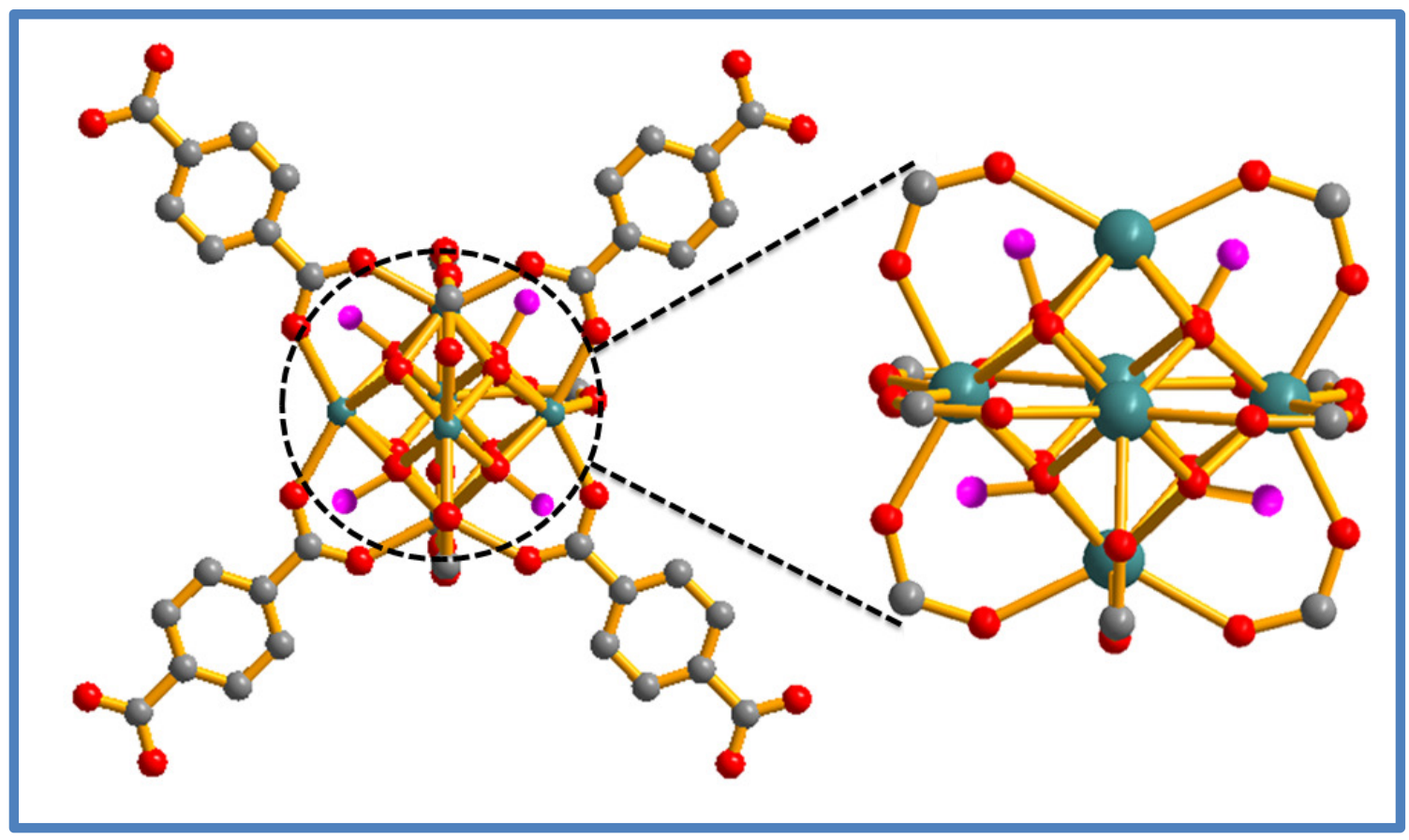

Figure S6. View of $\mathrm{Zr}-\mathrm{O}$ cluster/SBU of UiO-66 MOF showing the presence of hydroxide groups.

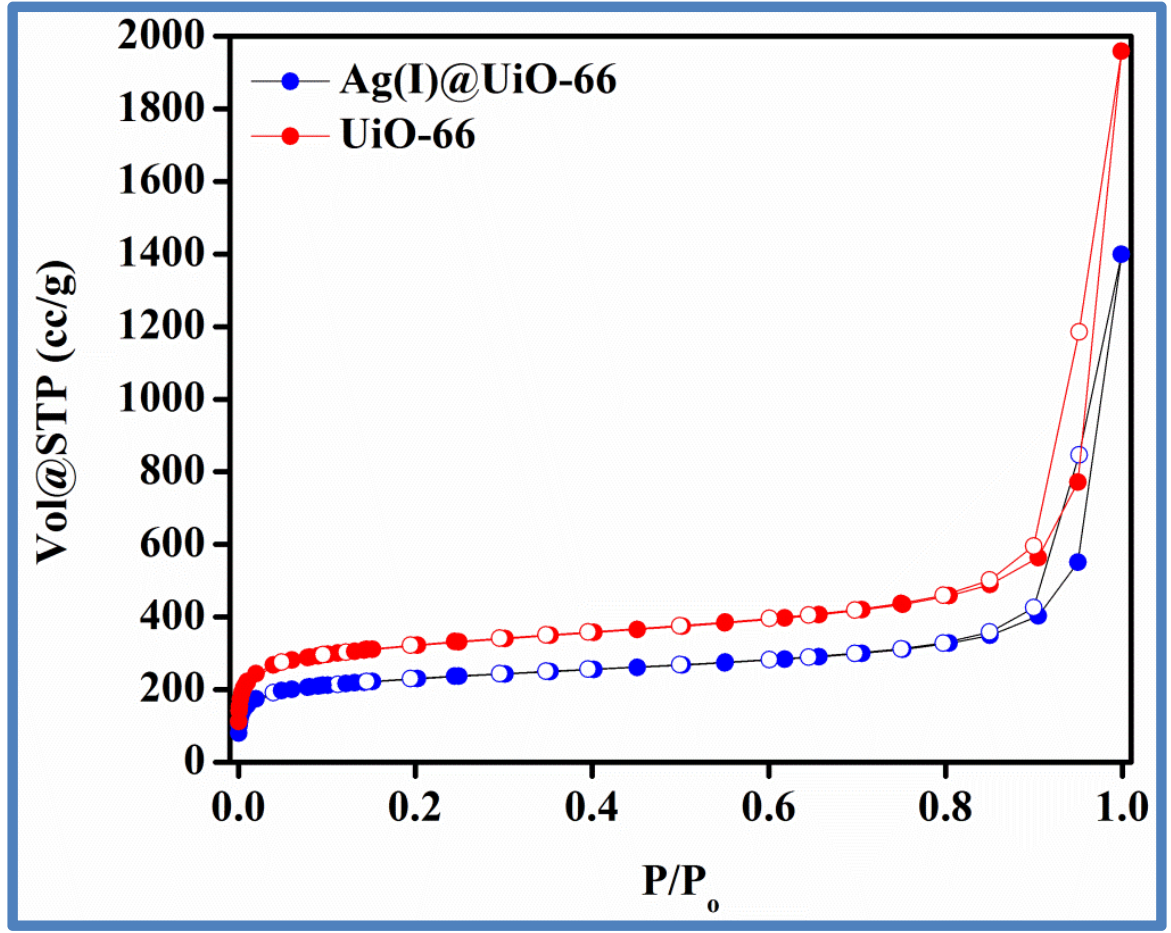

Figure S7. $\mathrm{N}_{2}$ adsorption-desorption isotherms for UiO-66 and $\mathrm{Ag}(\mathrm{I}) @ \mathrm{UiO}-66 \mathrm{MOF}$ carried out at $77 \mathrm{~K}$. 


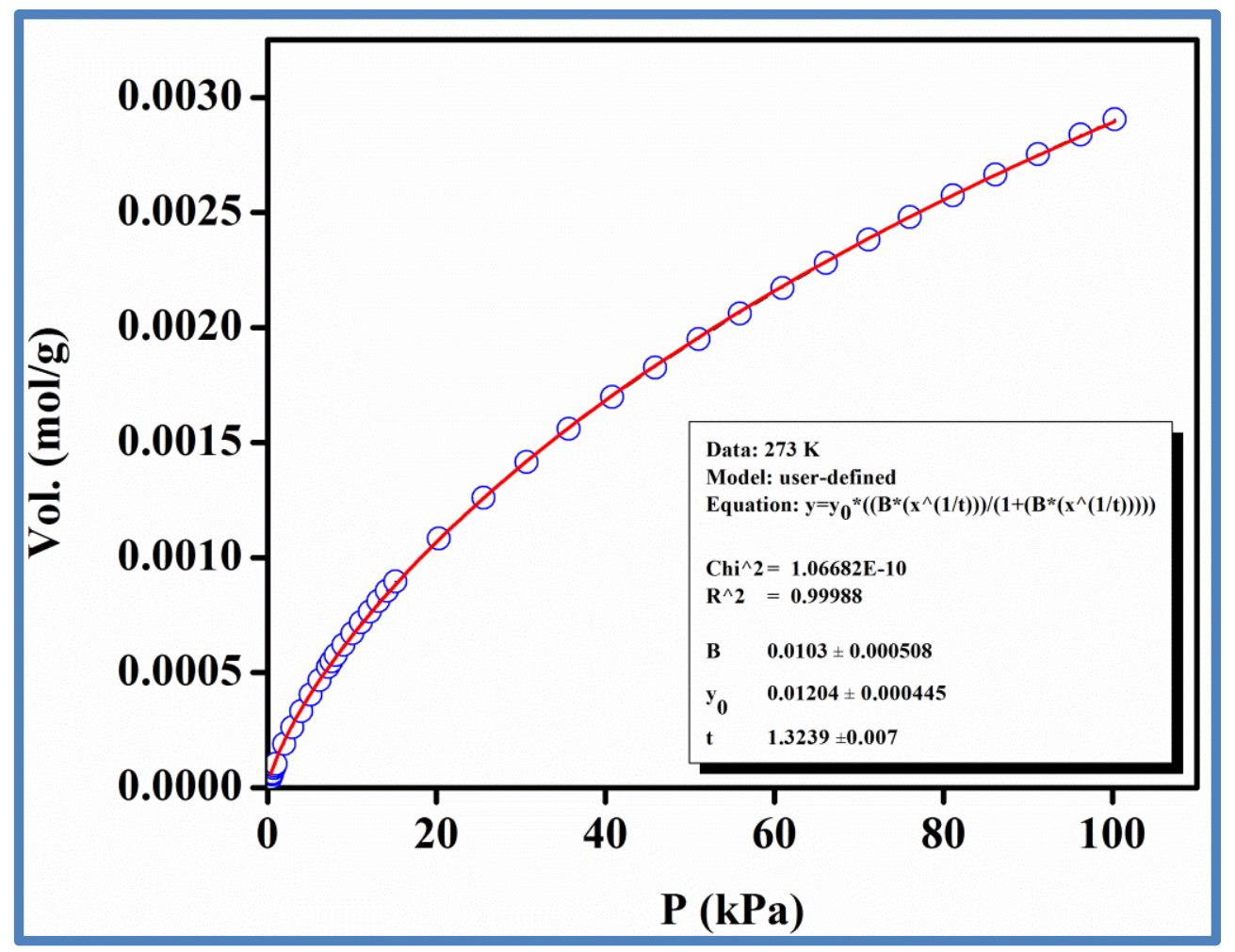

Figure S8. Carbon dioxide adsorption isotherm of $\mathrm{MOF}-\mathrm{SO}_{3} \mathrm{H}$ carried out at $273 \mathrm{~K}$. The solid line shows the best fit to the data using the Langmuir-Freundlich equation.

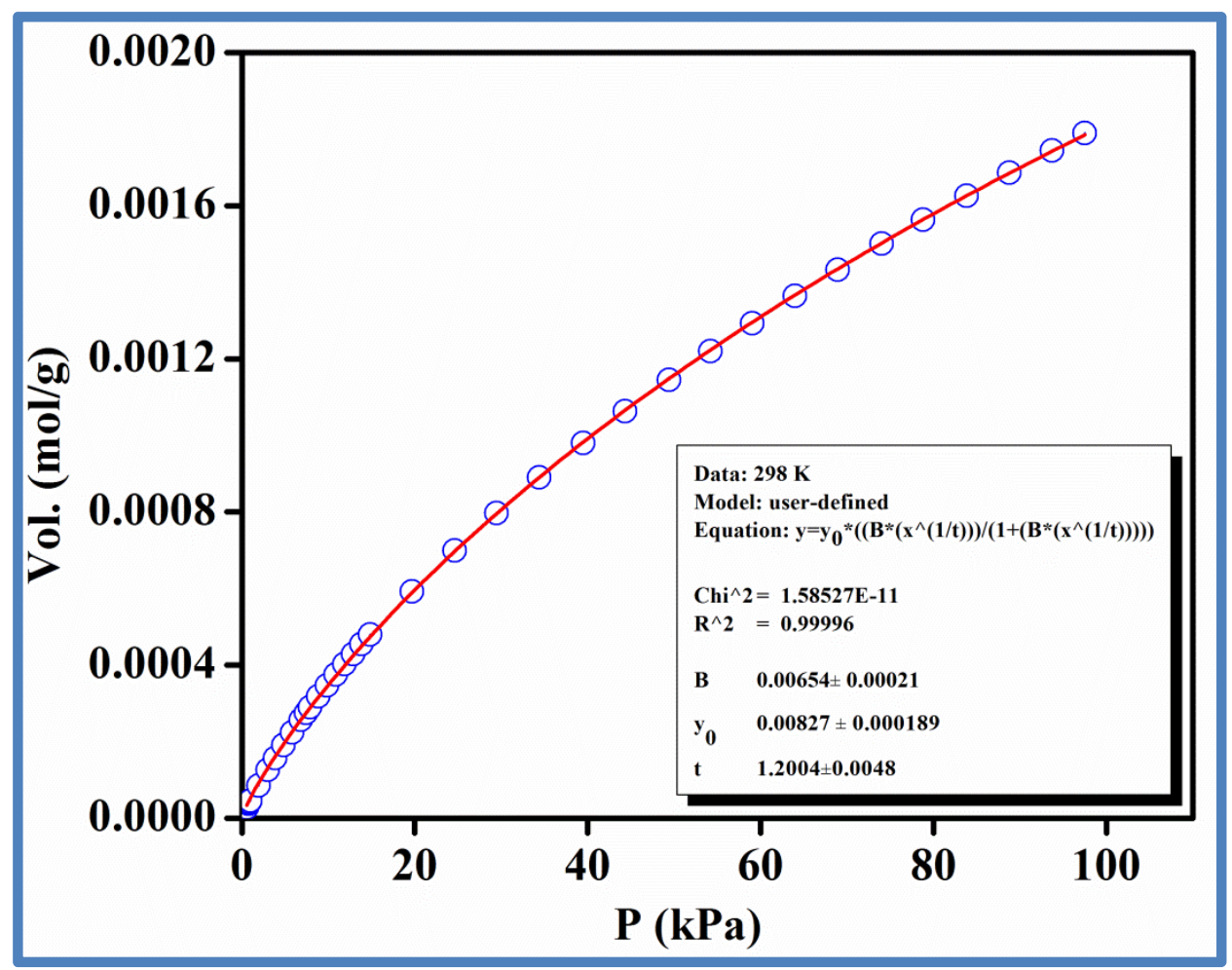

Figure S9. Carbon dioxide adsorption isotherm of $\mathrm{MOF}-\mathrm{SO}_{3} \mathrm{H}$ carried out at $298 \mathrm{~K}$. The solid line shows the best fit to the data using the Langmuir-Freundlich equation. 


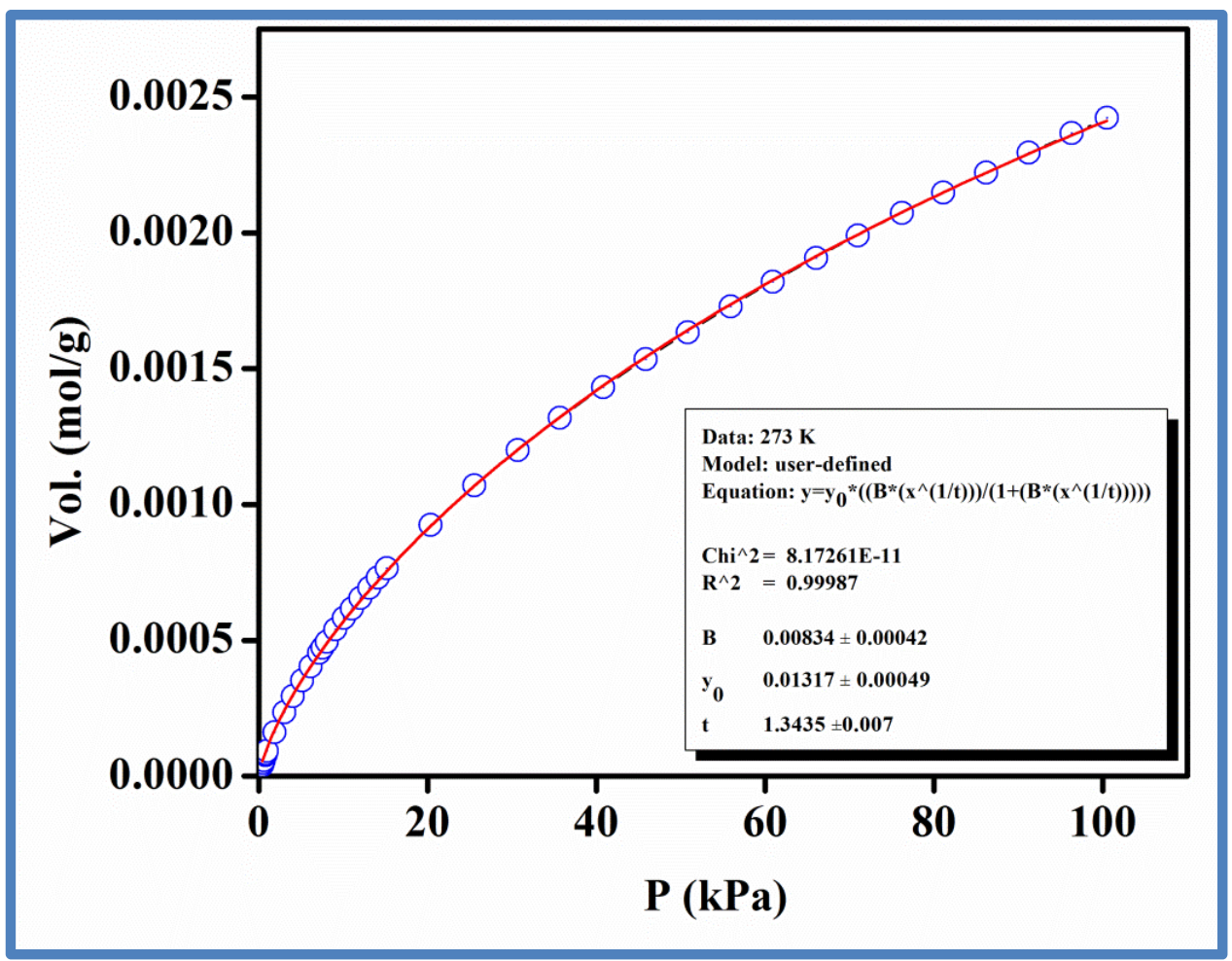

Figure S10. Carbon dioxide adsorption isotherm of $\mathrm{MOF}-\mathrm{SO}_{3} \mathrm{Ag}$ carried out at $273 \mathrm{~K}$. The solid line shows the best fit to the data using the Langmuir-Freundlich equation.

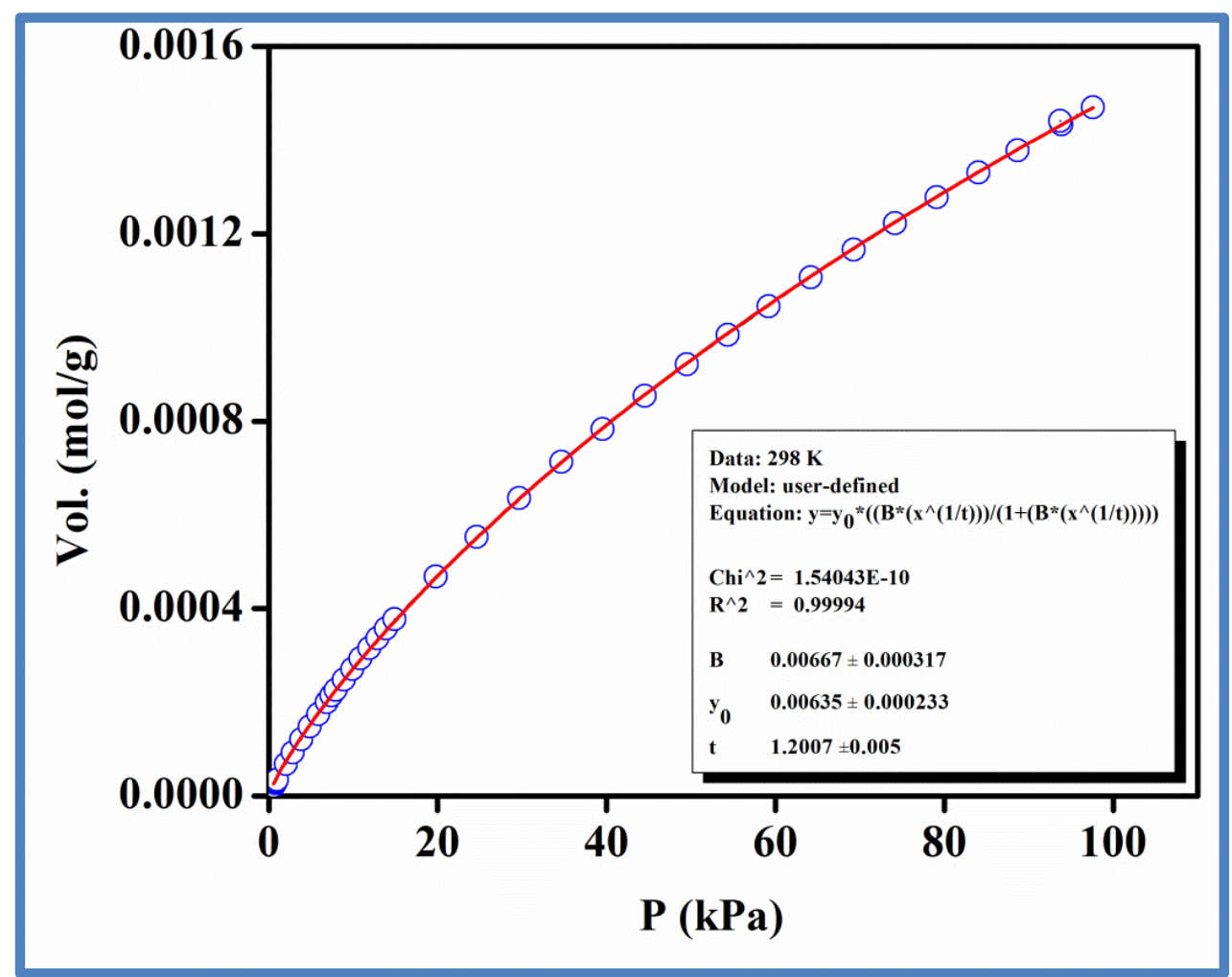

Figure S11. Carbon dioxide adsorption isotherm of $\mathrm{MOF}-\mathrm{SO}_{3} \mathrm{Ag}$ carried out at $298 \mathrm{~K}$. The solid line shows the best fit to the data using the Langmuir-Freundlich equation. 


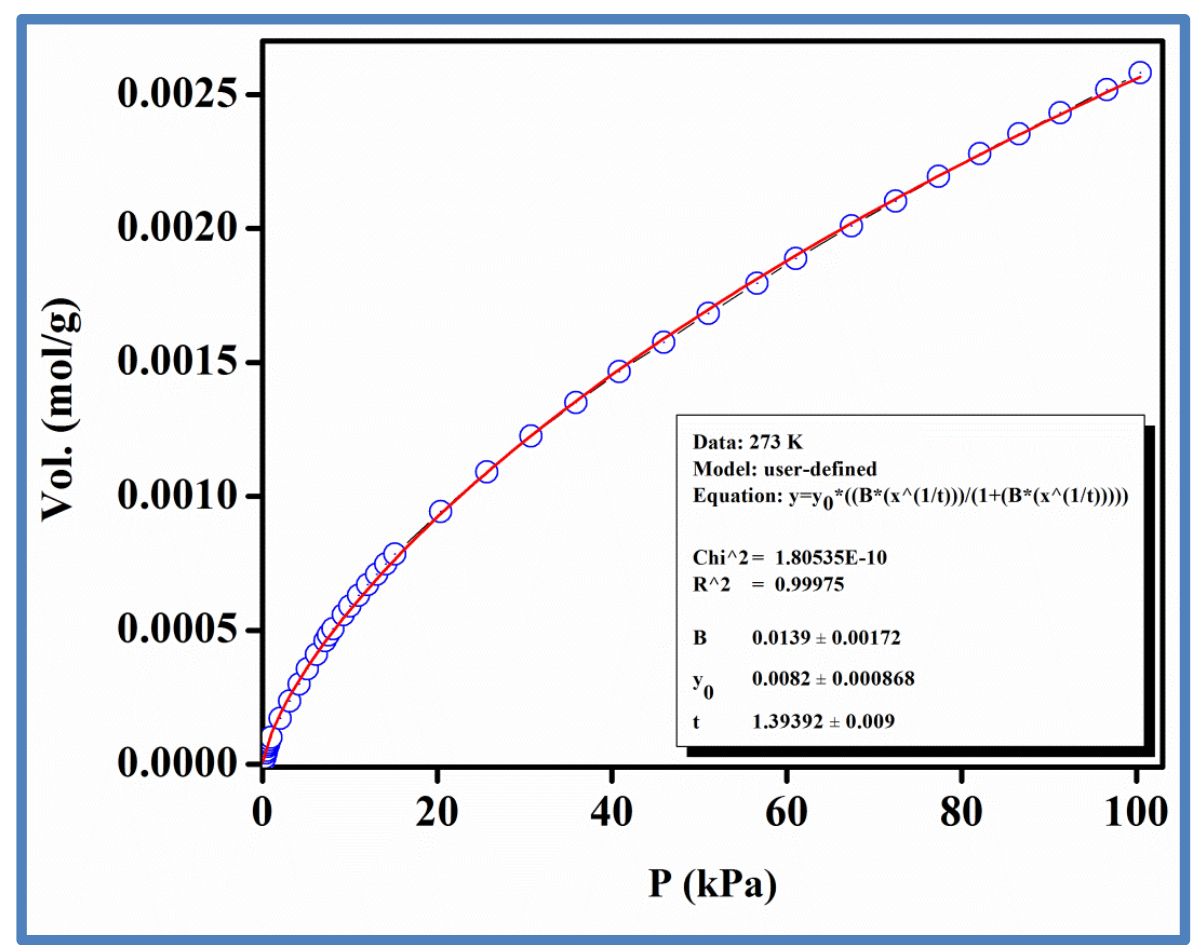

Figure S12. Carbon dioxide adsorption isotherm of $\mathrm{Ag}(\mathrm{I}) @ \mathrm{UiO}-66$ carried out at $273 \mathrm{~K}$. The solid line shows the best fit to the data using the Langmuir-Freundlich equation.

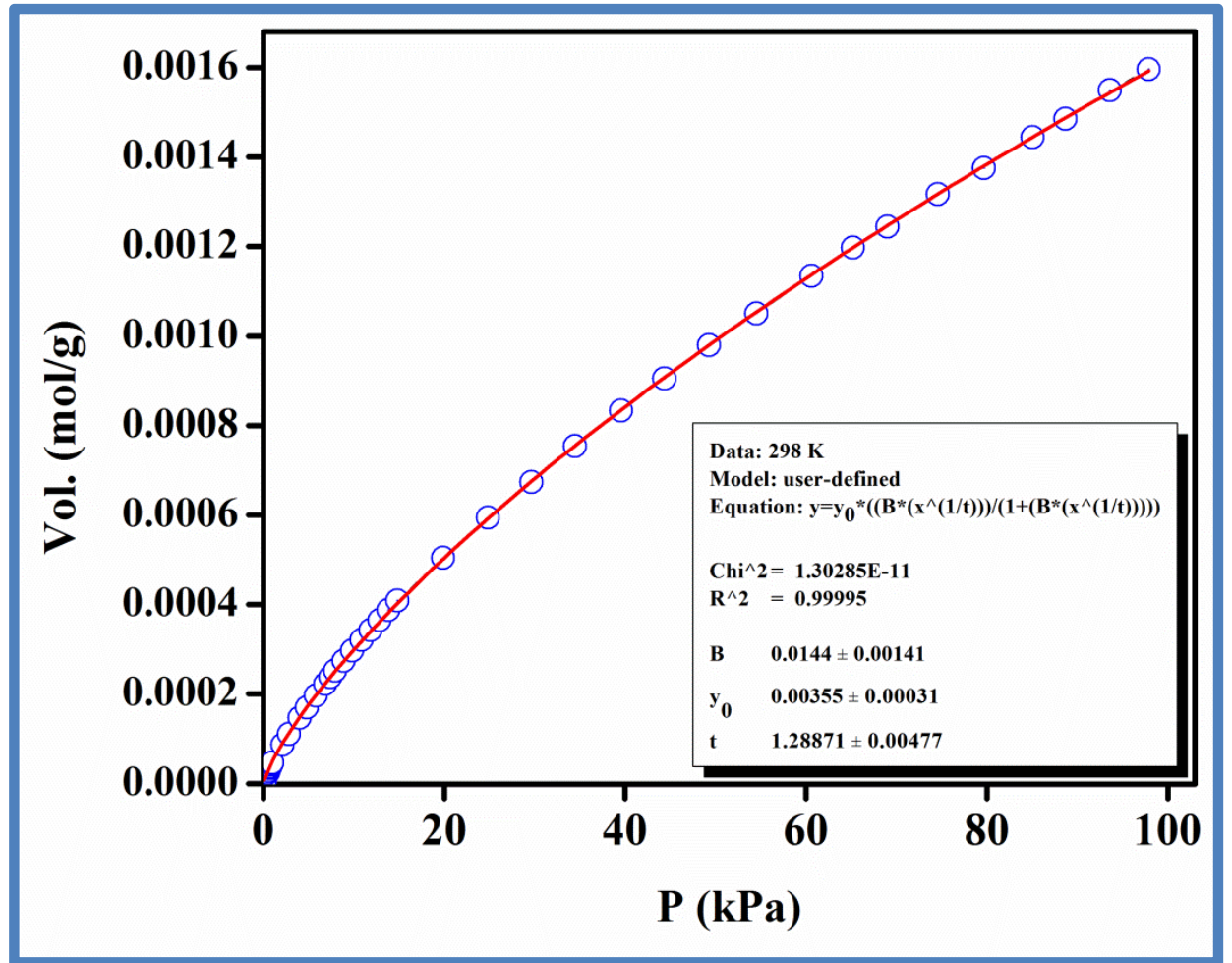

Figure S13. Carbon dioxide adsorption isotherm of $\mathrm{Ag}(\mathrm{I}) @ \mathrm{UiO}-66$ carried out at $298 \mathrm{~K}$. The solid line shows the best fit to the data using the Langmuir-Freundlich equation. 
Table S1. Comparison of $\mathrm{CO}_{2}$ heat of adsorption $\left(\mathrm{Q}_{\mathrm{st}}\right)$ value for $\mathrm{MOF}-\mathrm{SO}_{3} \mathrm{Ag}$ with $\mathrm{UiO}-66$ based MOFs.

\begin{tabular}{|c|c|c|c|}
\hline Sl. No. & UiO-66 based MOF & $Q_{\text {st }}(\mathrm{kJ} / \mathrm{mol})$ & Reference \\
\hline 1 & UiO-66 & 27 & 5 \\
\hline 2 & $\mathrm{UiO}-66-\mathrm{NH}_{2}$ & 28 & 5 \\
\hline 3 & UiO-66-Br & 28.4 & 6 \\
\hline 4 & UiO-66- $\mathrm{SO}_{3} \mathrm{H}\left(\mathrm{MOF}-\mathrm{SO}_{3} \mathrm{H}\right)$ & 30 & This work \\
\hline 5 & $\mathrm{Ag}(\mathrm{I}) @ \mathrm{UiO}-66$ & 30.1 & This work \\
\hline 6 & $\mathrm{UiO}-66-\mathrm{NO}_{2}$ & 32 & 6 \\
\hline 7 & UiO-66-OMe & 32 & 6 \\
\hline 8 & $\mathrm{UiO}-\mathrm{CO}_{2} \mathrm{H}$ & 33 & 6 \\
\hline 9 & $\mathrm{UiO}-66-\mathrm{SO}_{3} \mathrm{Ag}\left(\mathrm{MOF}-\mathrm{SO}_{3} \mathrm{Ag}\right)$ & 37.8 & This work \\
\hline
\end{tabular}

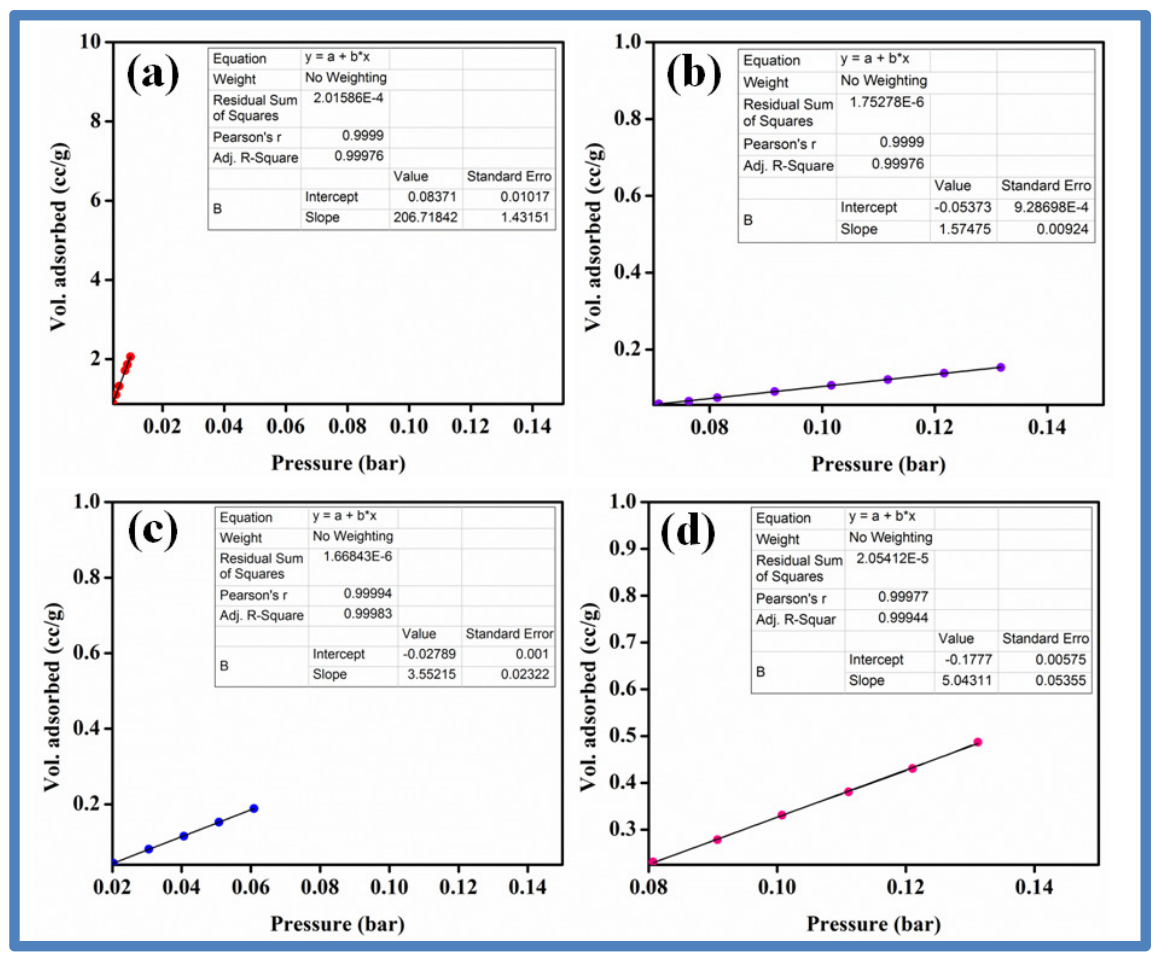

Figure S14. Calculation of Henry gas selectivity constants for gases $\mathrm{CO}_{2}, \mathrm{Ar}, \mathrm{H}_{2}$ and $\mathrm{N}_{2}$. 


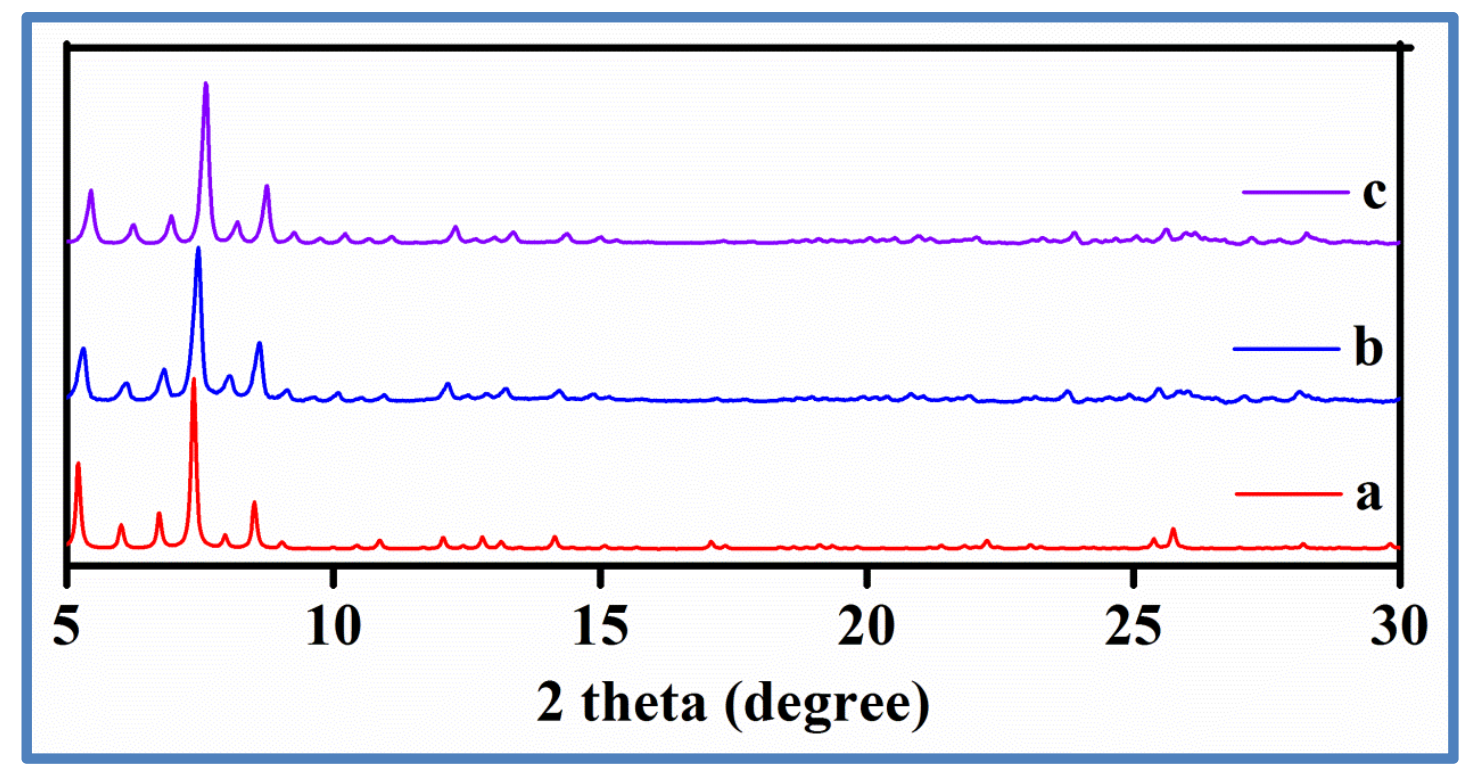

Figure S15. PXRD patterns of $\mathrm{MOF}-\mathrm{SO}_{3} \mathrm{Ag}$ (a) simulated pattern, (b) Activated $\mathrm{MOF}-\mathrm{SO}_{3} \mathrm{Ag}$, (c) After five cycles of $\mathrm{CO}_{2}$ adsorption.

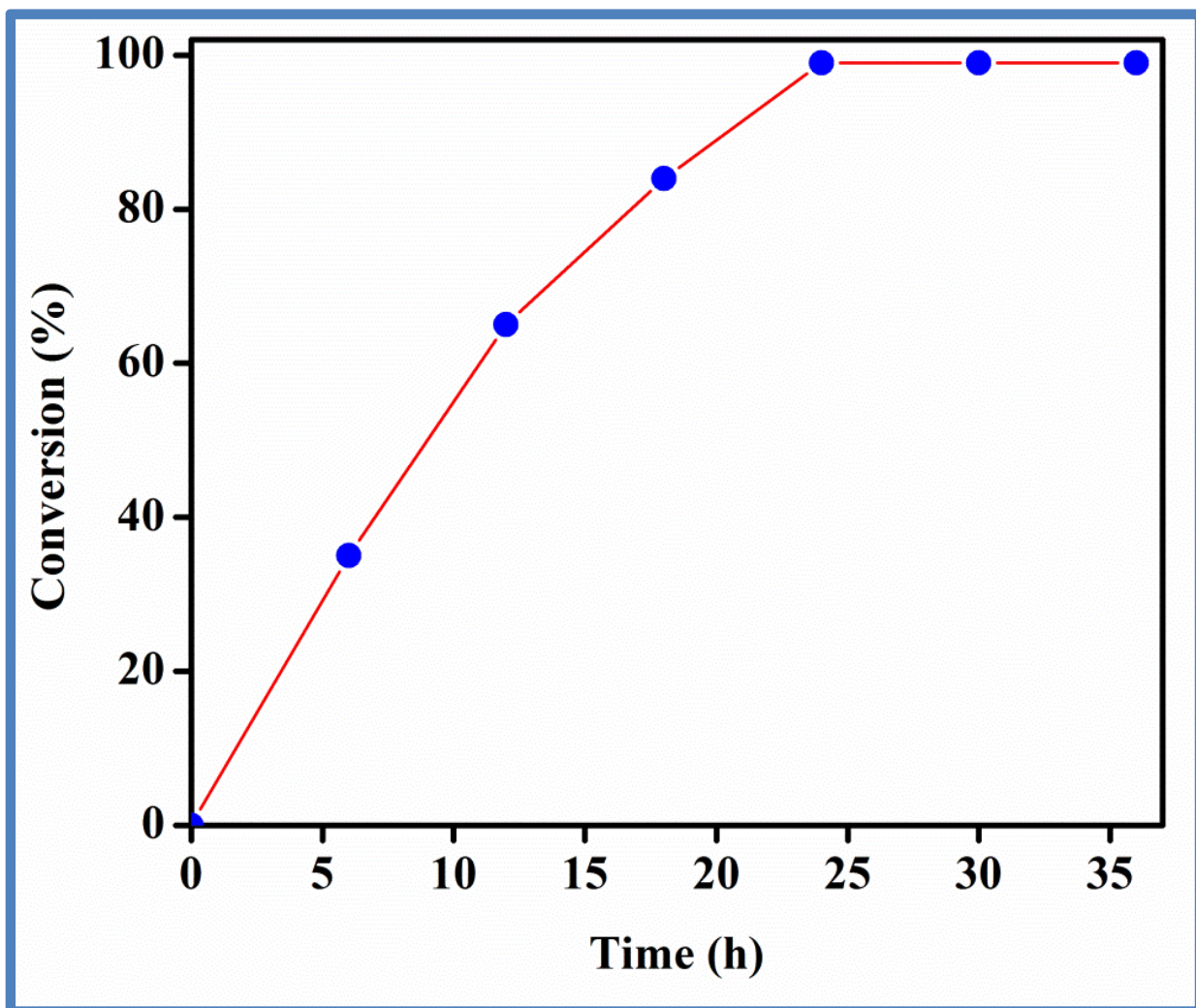

Figure S16. Reaction progress for cyclic carboxylation of 2-Methyl-3-butyn-2-ol with $\mathrm{CO}_{2}$ catalysed by $\mathrm{MOF}-\mathrm{SO}_{3} \mathrm{Ag}$. 


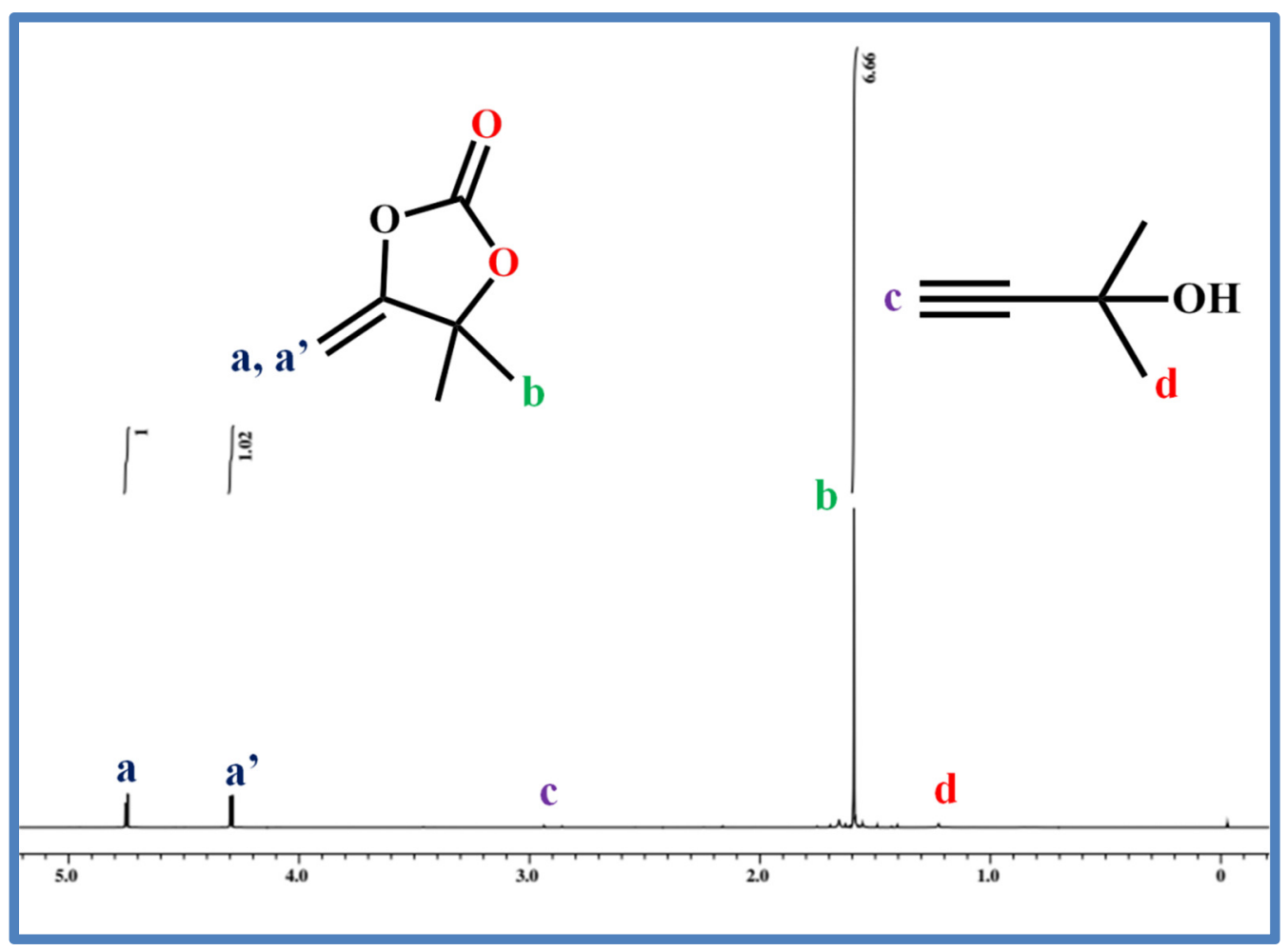

Figure S17. ${ }^{1} \mathrm{HNMR}\left(\mathrm{CDCl}_{3}, 400 \mathrm{MHz}\right)$ spectra for the cyclic carboxylation of 2-Methyl-3butyn-2-ol catalysed by MOF-SO 3 Ag after $24 \mathrm{~h}$.

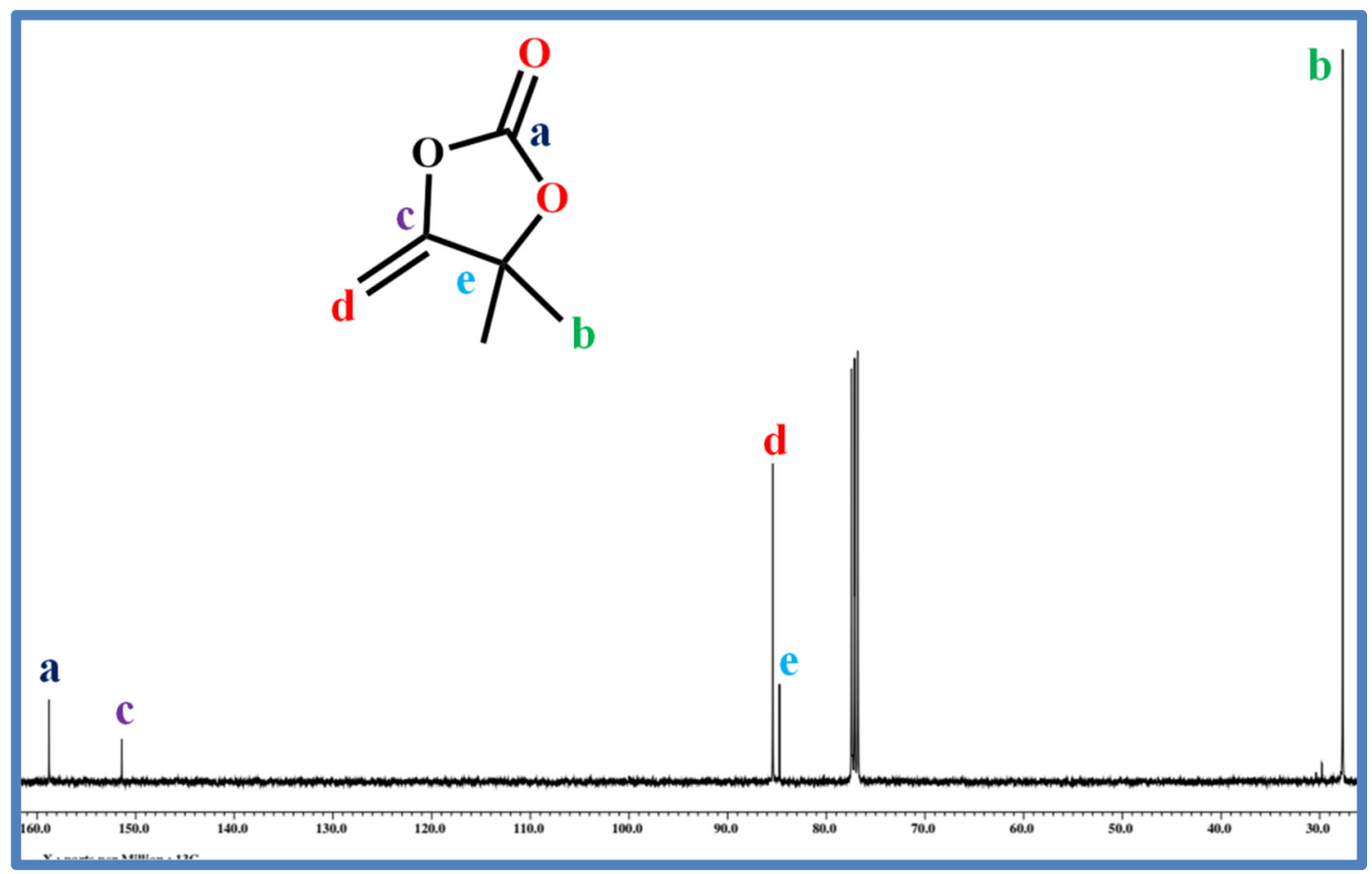

Figure S18. ${ }^{13} \mathrm{C}$ NMR $\left(\mathrm{CDCl}_{3}, 400 \mathrm{MHz}\right)$ spectra for the cyclic carboxylation of 2-Methyl-3butyn-2-ol catalysed by MOF-SO $3 \mathrm{Ag}$ after $24 \mathrm{~h}$. 


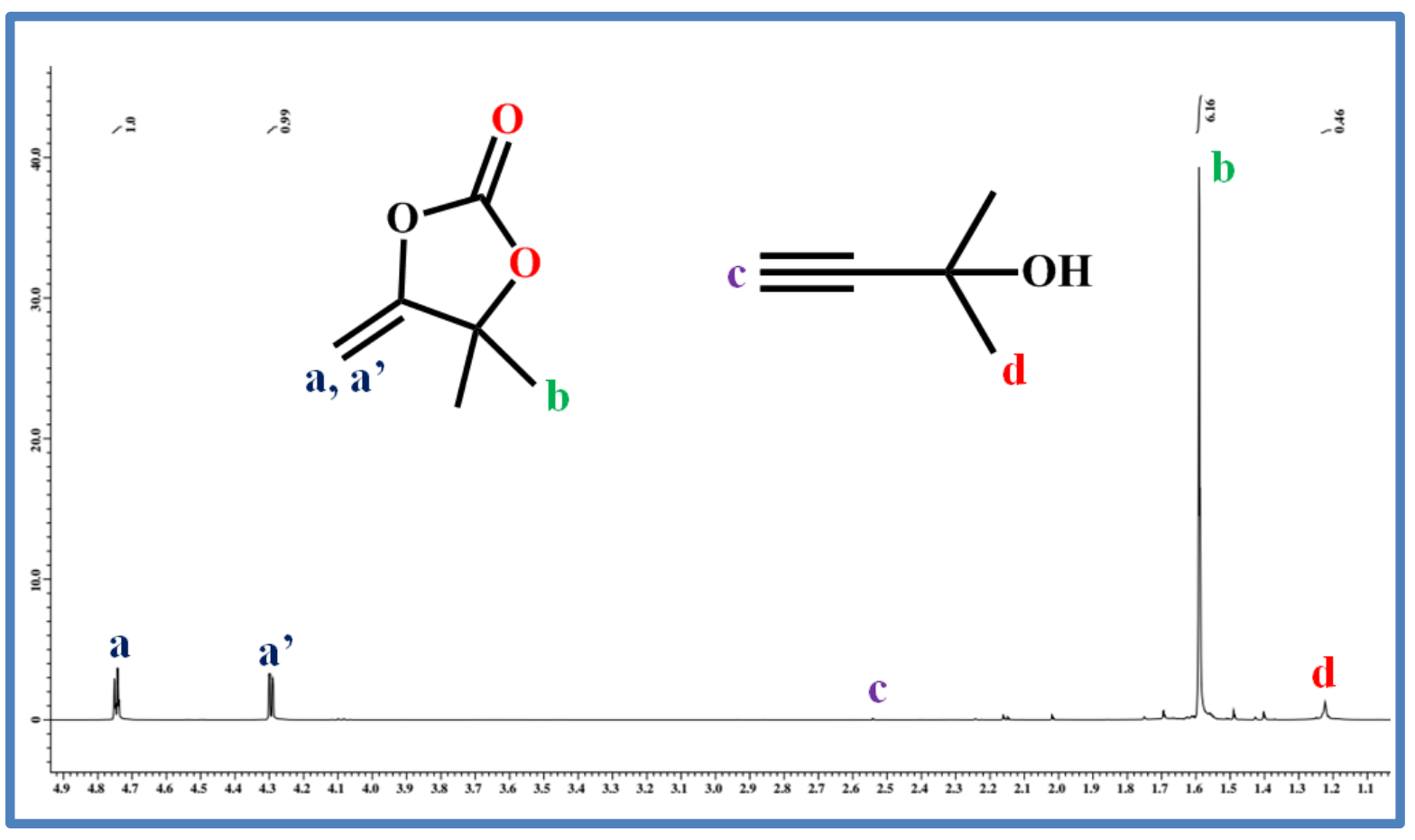

Figure S19. ${ }^{1} \mathrm{HNMR}\left(\mathrm{CDCl}_{3}, 400 \mathrm{MHz}\right)$ spectra for the cyclic carboxylation of 2-Methyl-3butyn-2-ol catalysed by Ag(I)@UiO-66.

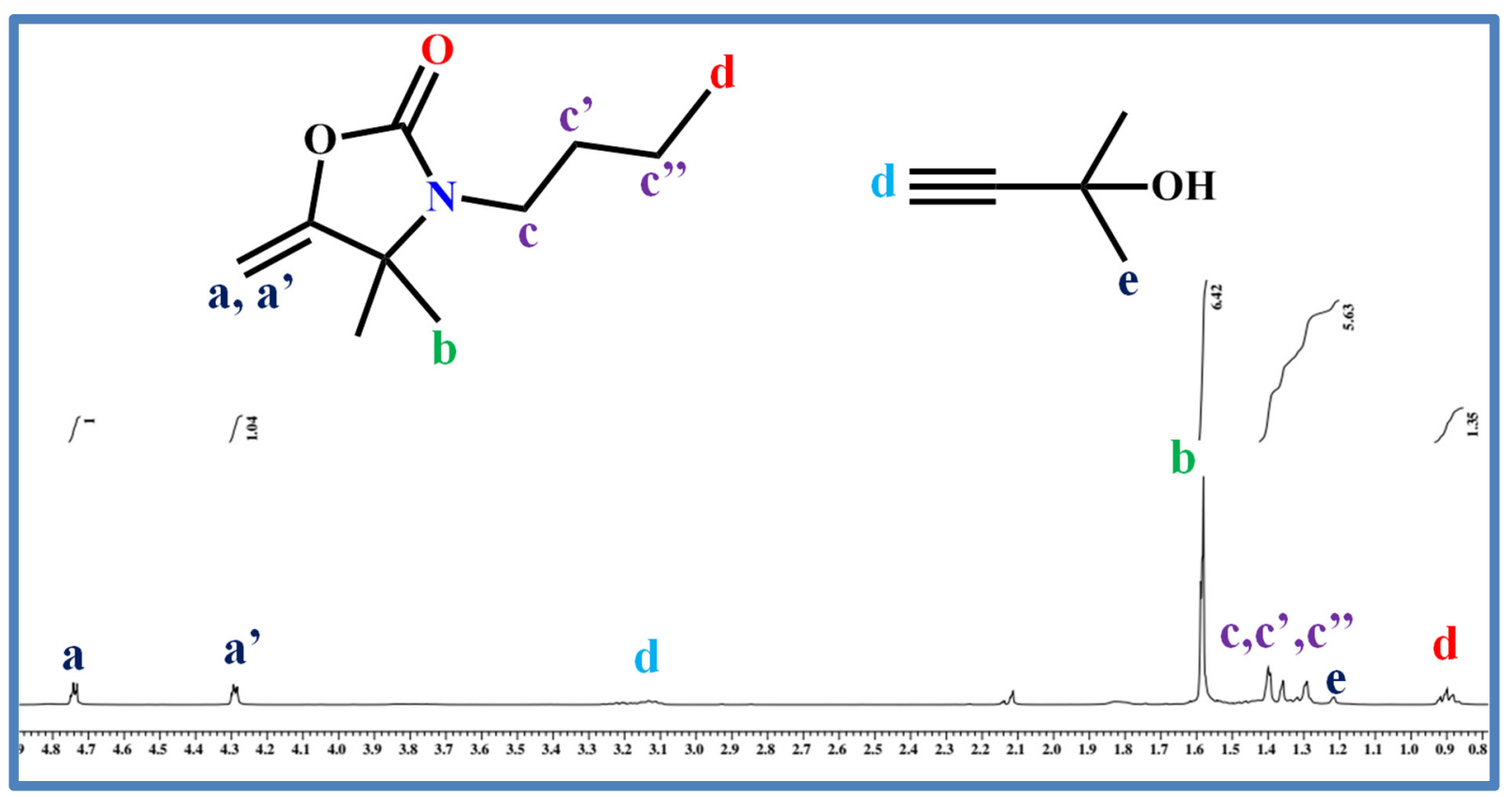

Figure S20. ${ }^{1} \mathrm{HNMR}\left(\mathrm{CDCl}_{3}, 400 \mathrm{MHz}\right)$ spectra for three-component reaction between $\mathrm{CO}_{2}$, 2-Methyl-3-butyn-2-ol and n-butylamine using $\mathrm{MOF}-\mathrm{SO}_{3} \mathrm{Ag}$ as catalyst. 


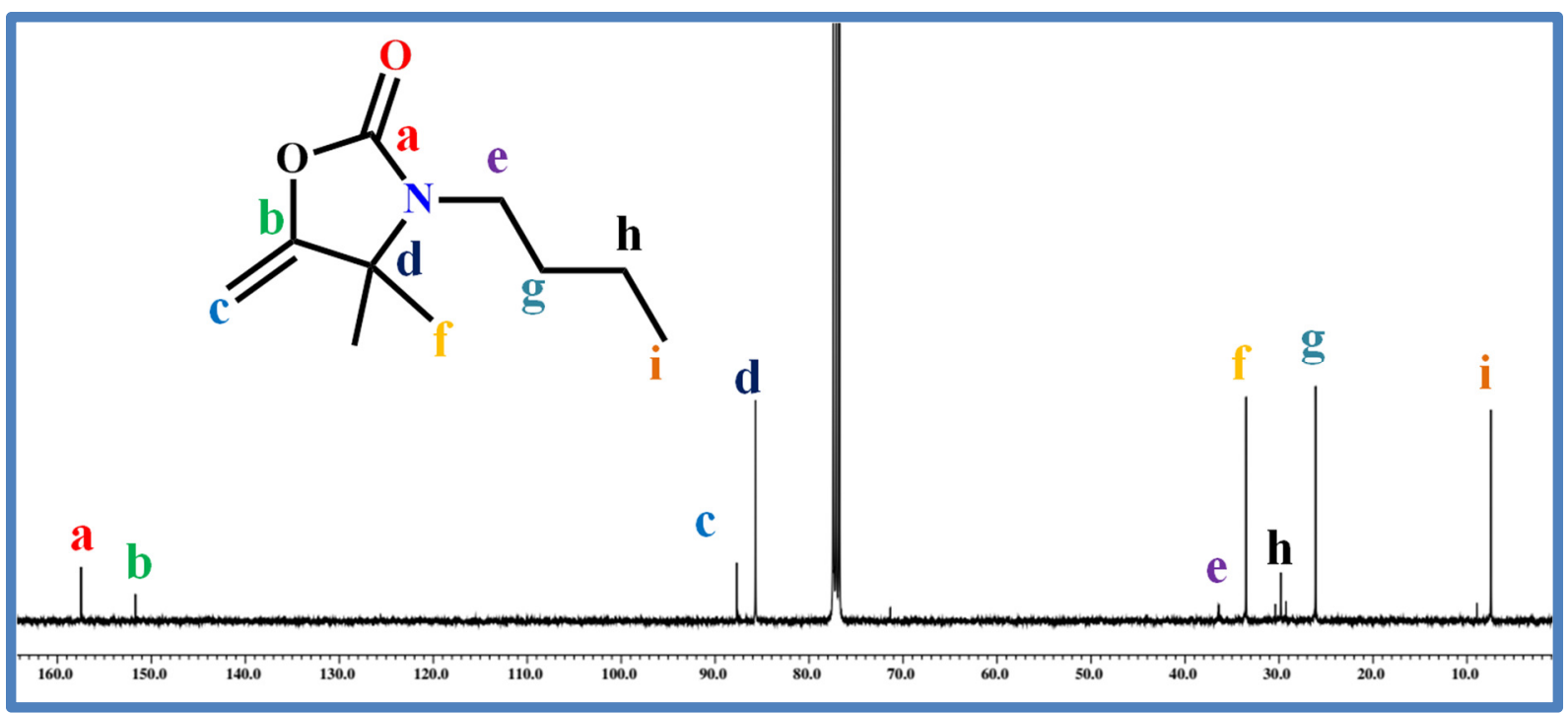

Figure S21. ${ }^{13} \mathrm{C} \mathrm{NMR}\left(\mathrm{CDCl}_{3}, 400 \mathrm{MHz}\right)$ spectra for three-component reaction between $\mathrm{CO}_{2}$, 2-Methyl-3-butyn-2-ol and n-butylamine using MOF- $\mathrm{SO}_{3} \mathrm{Ag}$ as catalyst.

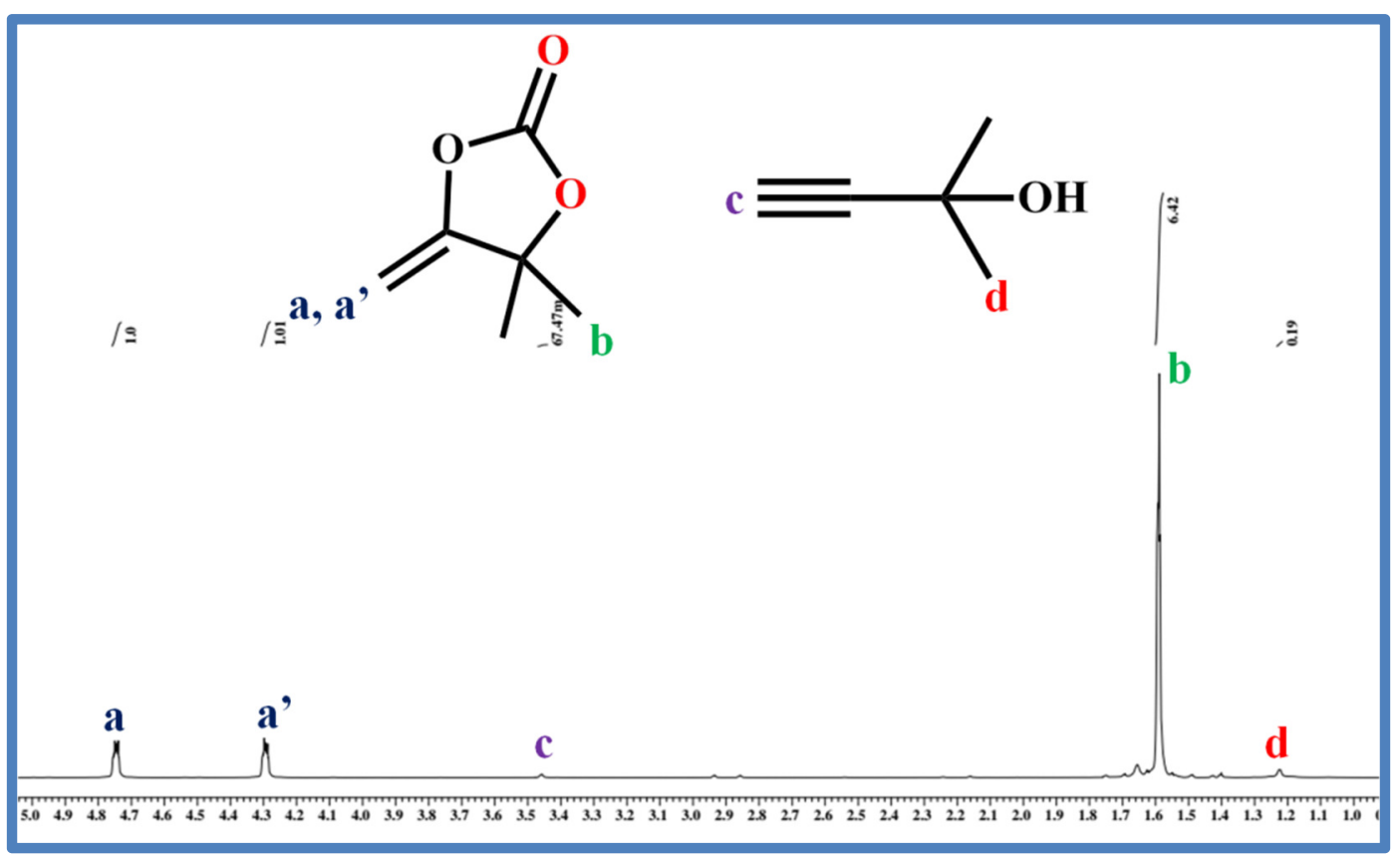

Figure S22. ${ }^{1} \mathrm{HNMR}\left(\mathrm{CDCl}_{3}, 400 \mathrm{MHz}\right)$ spectra for the cycloaddition reaction of 2- Methyl3-butyn-2-ol using MOF-SO $3 \mathrm{Ag}$ as catalyst fifth cycle. 


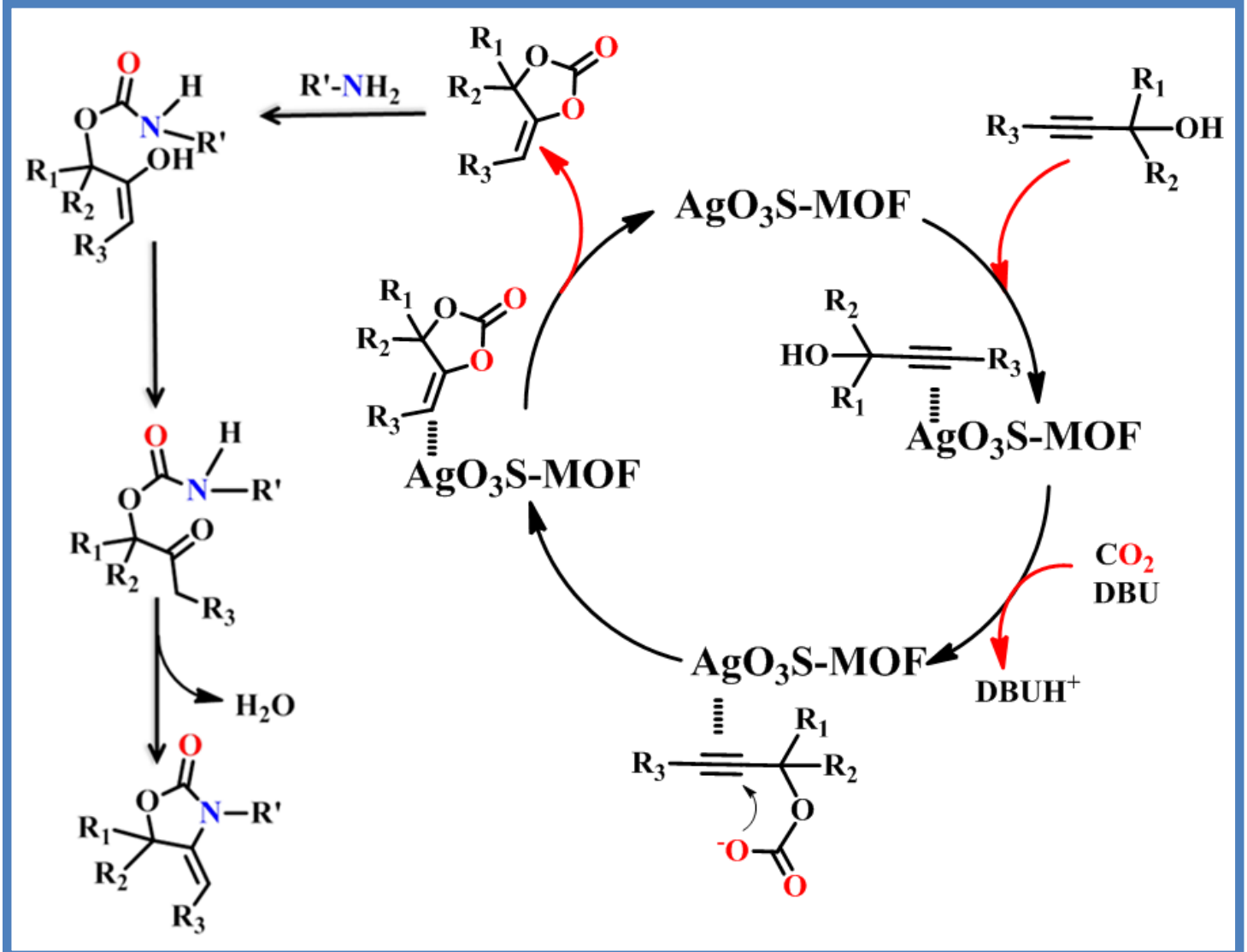

Scheme S1. Plausible mechanism for catalytic carboxylative cyclization of propargylic alcohol with $\mathrm{CO}_{2}$ catalysed by $\mathrm{MOF}-\mathrm{SO}_{3} \mathrm{Ag}$.

\section{References}

(1) Taylor, J. M.; Komatsu, T.; Dekura, S.; Otsubo, K.; Takata, M.; Kitagawa, H. The Role of a Three Dimensionally Ordered Defect Sublattice on the Acidity of a Sulfonated MetalOrganic Framework. J. Am. Chem. Soc. 2015, 137, 11498-11506.

(2) Moreira, M. A.; Santos, J. C.; Ferreira, A. F. P.; Loureiro, J. M.; Ragon, F.; Horcajada, P.; Shim, K. E.; Hwang, Y. -K.; Lee, U.-H.; Chang, J. -S.; Serre, C.; Rodrigues, A. E. Reverse Shape Selectivity in the Liquid-Phase Adsorption of Xylene Isomers in Zirconium Terephthalate MOF UiO-66. Langmuir 2012, 28, 5715-5723. 
(3) Pan, H.; Ritter, J. A.; Balbuena, P. B. Examination of the Approximations Used in Determining the Isosteric Heat of Adsorption from the Clausius-Clapeyron Equation. Langmuir 1998, 14, 6323-6327.

(4) Yang, R. T.; Gas Separation by Adsorption Processes, Butterworth, Boston, 1997.

(5) Cmarik, G. E.; Kim, M.; Cohen, S. M.; Walton, K. S. Tuning the adsorption properties of UiO-66 via ligand functionalization. Langmuir 2012, 28, 15606-15613.

(6) Yang, Q.; Wiersum, A. D.; Llewellyn, P. L.; Guillerm, V.; Serred, C.; Maurin, G. Functionalizing porous zirconium terephthalate $\mathrm{UiO}-66(\mathrm{Zr})$ for natural gas upgrading: a computational exploration. Chem. Commun. 2011, 47, 9603-9605. 